\title{
The impact of the financial system on economic growth in the context of the global crisis: empirical evidence for the EU and OECD countries
}

\author{
Mariusz Prochniak ${ }^{1} \cdot$ Katarzyna Wasiak $^{2}$
}

Published online: 30 March 2016

(c) The Author(s) 2016. This article is published with open access at Springerlink.com

\begin{abstract}
This study aims to analyze the impact of the development and stability of the financial sector on economic growth on the basis of the quantitative methods that produce robust results. The following research hypotheses are tested: /H1/ The relationship between financial sector development (stability) and economic growth is nonlinear; / $\mathrm{H} 2 /$ An excessively large size of the financial system does not lead to more rapid economic growth: it may even negatively affect GDP dynamics; /H3/ The inclusion of the post-crisis period gives new insights of the nature of the relationship between financial system and economic growth. The analysis covers the 28 EU and 34 OECD economies and the 1993-2013 period. The following variables are used to measure the financial sector: domestic credit provided by financial sector, bank nonperforming loans, bank capital to assets ratio, market capitalization of listed companies, turnover ratio of stocks traded, and the monetization ratio. A new element of the empirical analysis is the application of the extended econometric and economic modelling, including testing nonlinear relationships, analyzing both levels and changes of the financial variables, as well as estimating the models on the basis of a moving panel with overlapping observations. The regression equations are estimated by Blundell and Bond's GMM system estimator. Our results indicate that all the research hypotheses have been positively verified.
\end{abstract}

Mariusz Prochniak

mproch@sgh.waw.pl

Katarzyna Wasiak

katarzyna.wasiak@sgh.waw.pl

1 Department of Economics II, Warsaw School of Economics, Al. Niepodleglosci 162, 02-554 Warsaw, Poland

2 Treasury Department, Warsaw School of Economics, Al. Niepodleglosci 162, 02-554 Warsaw, Poland 
Keywords Financial development · Economic growth · European Union ·

Panel data $\cdot$ Empirical analysis

JEL Classification $\quad \mathrm{C} 23 \cdot \mathrm{F} 37 \cdot \mathrm{O} 47$

\section{Introduction}

There are many factors that can be treated as economic growth determinants. One of these factors is the financial system. The institutional framework of the financial system as well as its performance are no doubt important determinants of output growth. The theoretical structural model implies that the development and stability of the financial sector both have a positive impact on economic growth. However, when verifying this hypothesis on the basis of empirical data for real economies, some questions appear. First, is the positive relationship between the development of the financial sector and economic growth unconditional, or are there some constraints? Also, can a too big financial system hamper the growth rate of GDP? Second, what is exactly the stability of the financial system and how can it be measured on the basis of statistical data? The problems regarding the relationship between the financial sector and economic growth strengthened after the last global crisis and the crisis in the euro zone. It turns out that some disturbances observed in the financial sphere of the economy may exert very significant and long-term impact on the behavior of the real economy. The discussion of these issues is by no way closed. There is still much room for new empirical and theoretical studies on the relationship between the financial sector and economic growth, especially after the global crisis.

This study aims to analyze the impact of the development and stability of the financial sector on economic growth in the period covering the global crisis on the basis of the quantitative methods that produce robust results. The following three research hypotheses are tested: / $\mathrm{H} 1 /$ The relationship between financial sector development (stability) and economic growth is nonlinear; / $\mathrm{H} 2 /$ An excessively large size of the financial system does not lead to more rapid economic growth: it may even negatively affect GDP dynamics; /H3/ The inclusion of the post-crisis period gives new insights of the nature of the relationship between financial system and economic growth. We also present a wide literature review on the issues regarding the stability of the financial sector and the impact of the financial sector development on economic growth.

A new element of the empirical analysis as compared with the other studies on the subject is the application of the extended econometric and economic modelling. The new aspects include, among others, testing nonlinear relationships between financial development and economic growth, analyzing both levels and changes of the financial variables, as well as estimating the models on the basis of a moving panel with overlapping observations. Another aspect is the robustness analysis by including observations of different length. Such an approach constitutes the value added in the literature. 
The analysis covers the 28 EU countries and 34 OECD economies and the 1993-2013 period. The following variables are used to measure the development and stability of the financial sector: domestic credit provided by financial sector, bank nonperforming loans, bank capital to assets ratio, market capitalization of listed companies, turnover ratio of stocks traded, and the monetization ratio. All the regression equations are estimated on the basis of Blundell and Bond's GMM system estimator that is one of the best research techniques in the case of dynamic panel data growth regressions. Our results indicate that all the research hypotheses have been positively verified.

The paper is composed of five sections. The first section is this introduction. Section 2 discusses theoretical and empirical issues on the relationship between the financial sector and economic growth. Section 3 describes the econometric methodology applied in this study and the data used. Section 4 shows the presentation and interpretation of the results. The last section concludes.

\section{Theory and empirical evidence}

Taking into account the multitude of financial system definitions, the discussion should be started with an explanation of how different authors understand this term. We adopt the definition offered by Pietrzak et al. (2004, p. 19). They divide the financial system into the market one, constituting the mechanism of co-creation and flow of financial means, working then to the participation of private entities (financial institutions) and the public system, which in turn constitutes the mechanism assuring co-creation and flow of financial means allowing public government to provide public goods, services as well as public benefits. It is worth noting that definitions, which we encounter in different publications, have many common elements, complement each other rather than be mutually exclusive, but also stress different aspects of the financial system. One group is characterized by the structural-institutional approach, in the other though it is functional approach. The detailed overview of different available definitions of financial system, taking into account its functions, is done for example by Matysek-Jedrych (2007). The author makes an attempt herself to define the financial system, saying that it is the structure of "interconnected financial institutions, financial markets and elements of financial system infrastructure; through this structure, entities belonging to real environment (first of all households, enterprises and government) can source funding, invest savings and satisfy the rest of their needs relating to financial aspect of their functioning" (Matysek-Jedrych 2007, p. 14).

Based on the analysis of publications across the span of several decades it is clear that the interest in the financial system is rising. Research covers its different elements, as well as interrelations among them, and more often, especially as the result of the last crisis, the identification of risks for its stable and effective functioning, indicating, among others the occurrence of system risk.

The financial system is obviously also shaped by the development of nonfinancial sector. Its development pace and level depend on the individual country or regional economic conditions, including the institutional environment of the 
country, legal environment, political cycle etc. The increase of interest in the financial system directly results from its significance for the economy as the totality and its influence on the economic growth, which is particularly underlined by the authors of this paper. This theme was underlined in the scientific publications at the beginning of the 1990s, although more articles by authors like: Robinson (1952), Schumpeter (1960), Goldsmith (1969), McKinnon (1973), Shaw (1973) or Lucas (1988) do deserve careful attention and constitute the base for thesis being formulated in the span of the following years. Although at the beginning, the prevailing view was that there is an influence of the economic growth on the development of the financial system. Then in subsequent scientific research economists paid increasingly more attention to the causality between the financial system and economic growth, describing directions of these relationships as well as transmission channels. The knowledge in this regard was broadened both from a theoretical perspective as well as from a practical point of view. It is difficult however to identify the common thought in it. Quite on the contrary, the analysis indicates that economists' views differ. They can though be grouped in several streams (which have taken their origin in works of above mentioned authors), which makes it easier to make the overview of the problem of the influence of the financial system on the economic growth or speaking more in detail, the development of the financial system on economic growth. Following works by Al-Yousif (2002), four key areas of researched subject can be named. ${ }^{1}$

In the most extended view-supply-leading view - the key role is played by the supply of financial services, and the main thesis is that the financial development positively influences the economic growth. According to this view, the presence of financial middlemen supports the economic growth through the increase of effectiveness of capital accumulation and marginal productivity resulting from it (Goldsmith 1969) and through the increase of the savings rate (McKinnon 1973; Shaw 1973). Such a theoretical point of view is confirmed by e.g. Bencivenga and Smith (1991), Greenwood and Jovanovic (1990) or Levine (2004).

The second view in research papers-demand-following view-underlines the following aspect: the development of the financial system is not an element which determines economic growth but it is only a result of actual demands of economy. Commercial entities encouraged by the market create additional demand for more and more advanced financial services and financial institutions, which want to meet this increased demand, have to further develop. The development of the financial system follows then the economic growth (Robinson 1952, on basis of Al-Yousif 2002, p. 132). This theory is supported by empirical research conducted by Friedman and Schwartz (1963) and Ireland (1994).

It is also worth mentioning the works by Demetriades and Hussein (1996), and Greenwood and Smith (1997), in which the authors equally treat two elements discussed above underlining that there is bidirectional causality between them. Of the contrary opinion is Lucas (1988) who claims that it is not appropriate to put such a significant attention on the role of the financial system as the factor of economic growth, as this role is insignificant.

\footnotetext{
${ }^{1}$ Detailed description of publications can be found in: Levine (1997).
} 
Channels through which the financial system is influencing the economic growth are first of all accumulation of the capital and the change in the productivity of production factors. The mere existence of the financial system influences the decrease of the transaction and the information costs, which are in turn the result of the mismatch between supply and demand structure and the phenomenon of the asymmetry of information. The financial system enables the more effective allocation of resources in conditions of uncertainty. The better it completes this function, the more significant positive influence on the economy is noted (Levine 1997, p. 690-691).

An efficient and effective banking system and financial markets create a positive impact on the overall wealth of society, by enabling the advantageous flow of financial means accessibility in any given time. This contributes to the rise of consumption levels and subsequently production rates and economy effectiveness (Mishkin 2002, p. 54). Scientific publications also indicate that the economic development is one of the most important deep determinants of economic growth (Marcinkowska et al. 2014, p. 22). ${ }^{2}$

While setting up the econometric models aimed at confirmation of one of the above mentioned views, it is important to clearly differentiate causal relationship of variables and statistical correlation. Variables, even though often correlated, are not linked by causality. A separate issue is whether the economic growth is treated as a dependent variable. Both approaches find confirmation in the theory of economic thought.

Arestis and Demetriades (1997) pay attention to the fact that while researching causality between the financial system and the economic growth, one faces methodological challenges that sometimes make it impossible to identify these relationships. There are also problems with availability of statistical data.

Based on the analysis of scientific publications, it can be stated that it is not possible to give an unambiguous answer to the question whether interrelations between the financial system development and economic growth are of unidirectional character (if so, then which way) or bidirectional. Existing empirical research confirms different theoretical approaches in this area (see: Shan et al. 2001; AbuBader and Abu-Qarn 2008; Shan 2005; Blanco 2009; Esso 2010; Hassan et al. 2011).

Making the analysis of the methodology of the research in the discussed subject, it is worth indicating several key arguments present in the discussion resulting from empirical research. The financial system:

- Accumulates savings, assuring at the same time wide access to its diversified forms,

- Enables the more effective allocation of gained savings, among others thanks to specialized knowledge of financial consultants (middlemen) who in turn contribute to the risk management through on going monitoring of debtors,

\footnotetext{
${ }^{2}$ Factors determining economic growth can be divided into shallow and deep (i.e. Rodrik 2002, 2003, 2004), which is important from the point of view of the possibilities in explaining deepening differences in the levels of economic growth of different countries. See also: Marcinkowska et al. (2014).
} 
- Enables the reduction of risk undertaken by individual investors, thanks to the diversification of assets portfolio,

- Is the source of liquidity, thanks to which savers have easy access to accumulated resources (Matysek-Jedrych 2007, p. 47).

Large portion of empirical research, including those at the level of commercial enterprises, economy branches or different countries, represents strong positive correlation between functioning of financial system and long-term economic growth. Theory and empirical evidence both deny the fact that, allegedly, the financial system only-and in the automatic way only-reacted to the needs of economy. The confirmation of the above thesis might be, for example, empirical research conducted by King and Levine (1993) or Rousseau and Sylla (1999, 2001).

Creel et al. (2015) test whether financial stability has a causal effect on economic performance and its subcomponents: consumption, investment and disposable income on different samples of EU countries. The benchmark period was 1998-2011 and they used proxy data to extend the analysis from 1960. The authors used different financial instability indicators that measure the macro and micro dimensions of financial stability: the Composite Indicator of Systemic Stress (CISS, provided by the EBC), aggregate prudential ratios for domestic banks for each country, stock market volatility and own statistical index constructed on the basis of principal component analysis. Creel et al. found that financial instability has a negative effect on economic performance. Their results also suggest that the level of financial depth in the EU is relatively advanced and finance effects are not favorable to economic growth. On the contrary, the deepening of finance bears some risks through the negative effects induced by financial instability. It suggests that the argument by bank lobbies, i.e. that regulating the size and growth of the financial sector would negatively impact economic growth, is not supported by the EU data.

The financial system can and often does positively influence economic growth but it can also be the barrier to growth. Too much of its development can create the risk for its effective functioning. It will also contribute to the increased risk of the large-scale financial crisis. Opportunity to realize high profits, in connection with human giddiness, can induce temptation of moral hazard. It seems then, that the conclusion can be made that some results of the current financial crisis can be attributed to the consent of supervisors to too dynamic development of the financial system. Its size has to strictly correspond with the needs of the economy.

The above is reflected in the studies by Deidda and Fattouh (2002), Arcand et al. (2012), and Cecchetti and Kharroubi (2015). These authors, on the basis of empirical research, demonstrate that the correlation between the financial sector and economic growth is not linear but adopts the shape of letter U, upside down. Researchers have not identified the positive correlation between the size of the financial sector and economic growth in the case of countries with very large financial sector presence. Such a correlation is however positive (but only to a certain point) in countries where the financial sector is small or medium. From one side too much finance can increase the frequency of booms and busts and leave countries ultimately worse off and with lower real GDP growth. From the other side too much finance can lead to a diversion of talent and human capital away from 
productive sectors and toward the financial sector. Some economists argue that a very large financial sector may rent extraction from other sectors, which would lead to a misallocation of resources.

Relating the above to the actual values when borrowings for the private sector exceed the level of $80-100 \%$ of GDP the financial system starts to negatively influence the economic growth. Taking into account the employment levels in the financial sector it was stated that the negative influence on the increase of effectiveness rate occurs when the share of these employment levels in total employment rate in the economy exceeds $3.5 \%$. The other research that is quoted by National Bank of Poland in its report concerning the development of the financial system describes the following threshold values, which, if exceeded, cause the financial system influence on the economic growth to become negative: borrowings for the private sector in relation to the GDP-88-95\%, liquid liabilities-91\% of GDP, total local borrowings-99 \% of GDP (NBP 2014, p. 18-19). Given these results, it is justified to test nonlinear relationships as applied in our study.

The subject of index of borrowings by the private sector in relation to GDP and also the liquidity of the stock exchange is mentioned by Levine and Zervos (1998). They have conducted the analysis for 42 countries during the 1976-1993 period, concluding that these values are of positive correlation with future rates of economic growth, capital accumulation and productivity growth.

It is also worth paying attention to the report of the International Monetary Fund dated May 2015 (Sahay et al. 2015). The authors of the cited report present the new index, the role of which is to evaluate the level of the development of the financial system. It is called Financial Development Index (FD Index). This index takes into account financial institutions and financial markets and also depth, access, and efficiency of each of these elements. The research was conducted in 176 countries in the period from 1980 to 2013. The index adopts values from 0 to 1 and is linked with the influence of whole financial sector on the real economy. In order for the financial system to optimally influence the economic growth, the value of the FD Index should oscillate in the range between 0.4 to almost 0.7 points. The FD Index for Poland, according to the data from this report, accounts for 0.5 points. It is, according to IMF, the ideal value. One should obviously not become too excited about this but all effort should be made for the financial system to be appropriately supervised and controlled in order to assure its maximum safety and stability.

Another conclusion from the IMF report is that financial stability risks increase with financial institution depth. In this report financial stability is approximated by the z-score, which measures the amount of buffers the banking system has to guard against shocks to earnings. A lower z-score means a lower distance-to-distress, that is, bigger financial stability risks. The findings imply that with increasing depth of financial institutions, buffers tend to decline, other things being equal (Sahay et al. 2015, p. 22).

In general, the report confirms conclusions from earlier studies, concerning positive influence of the financial system development on the economic growth.

Table 1 shows the extended review of empirical studies on the relationship between the financial system and economic growth. The respective columns in the table indicate the variables which are used to measure financial sector development, 


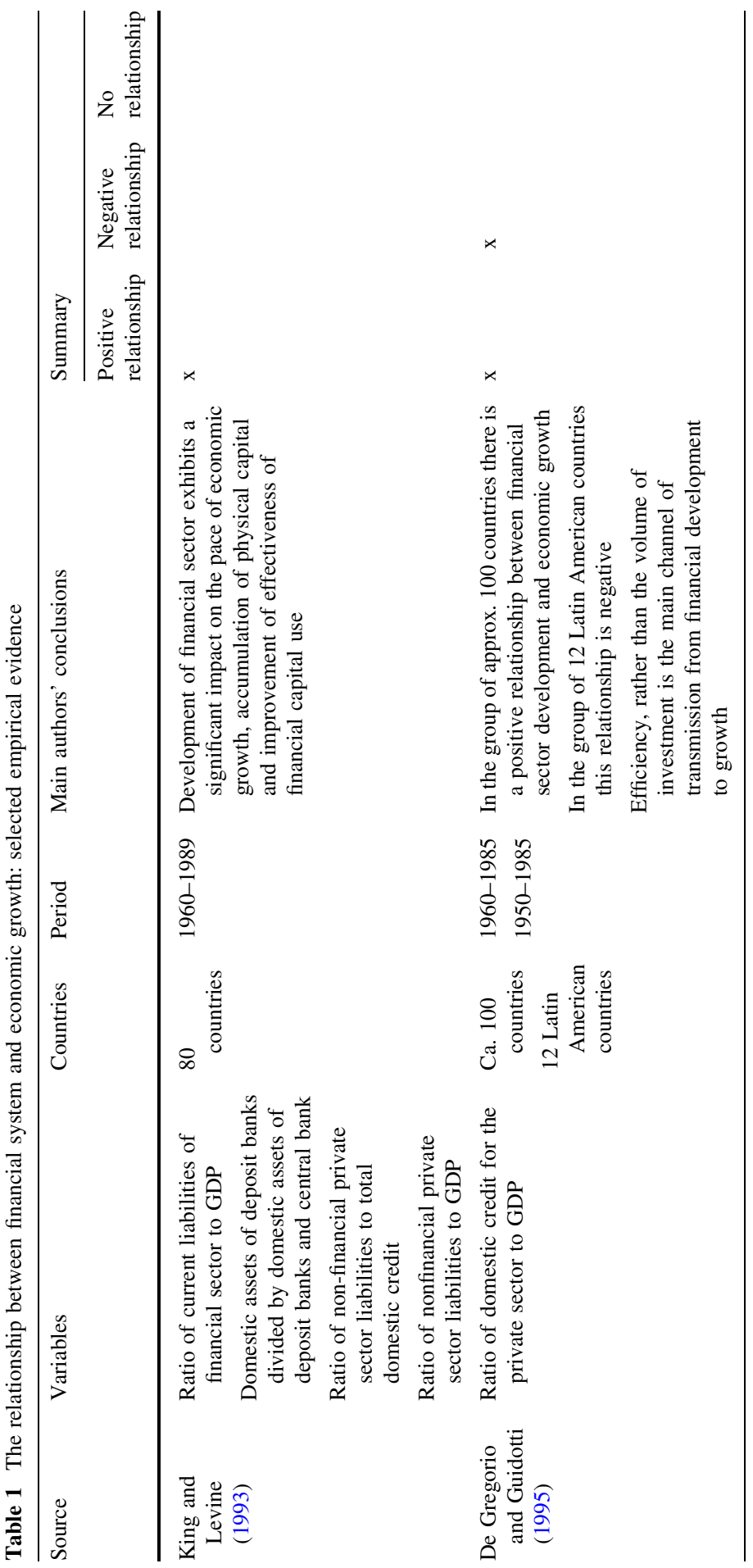




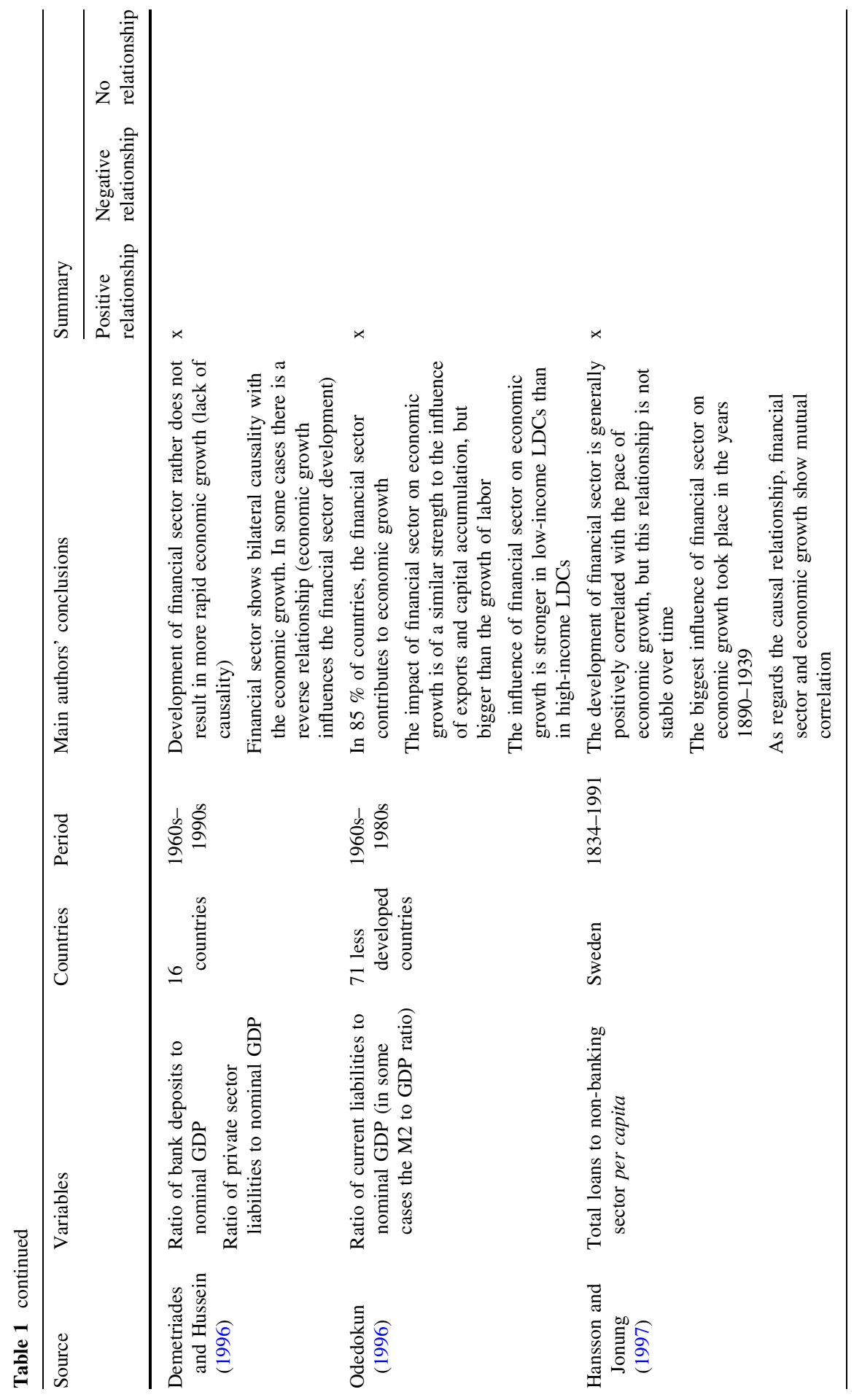




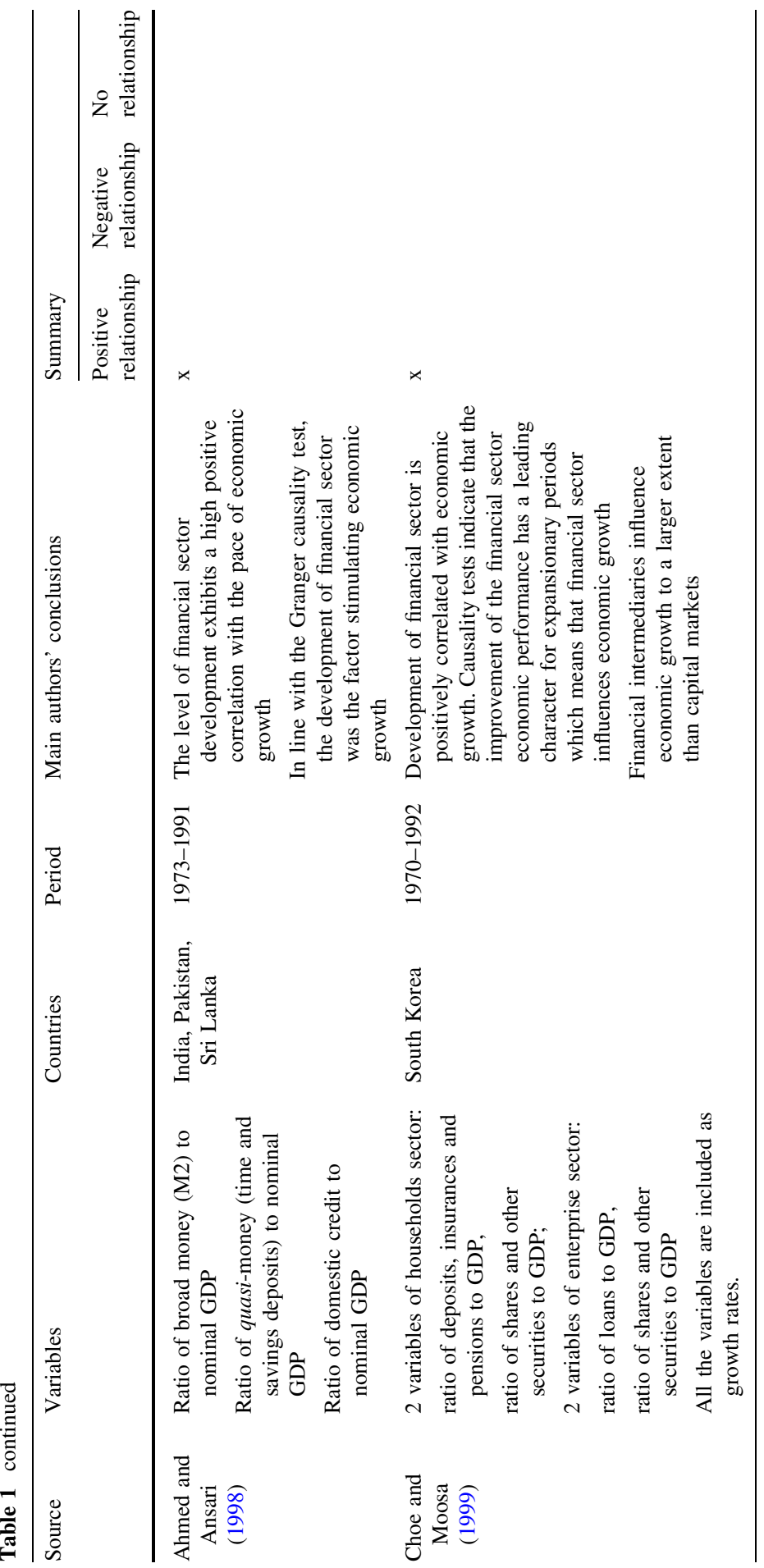




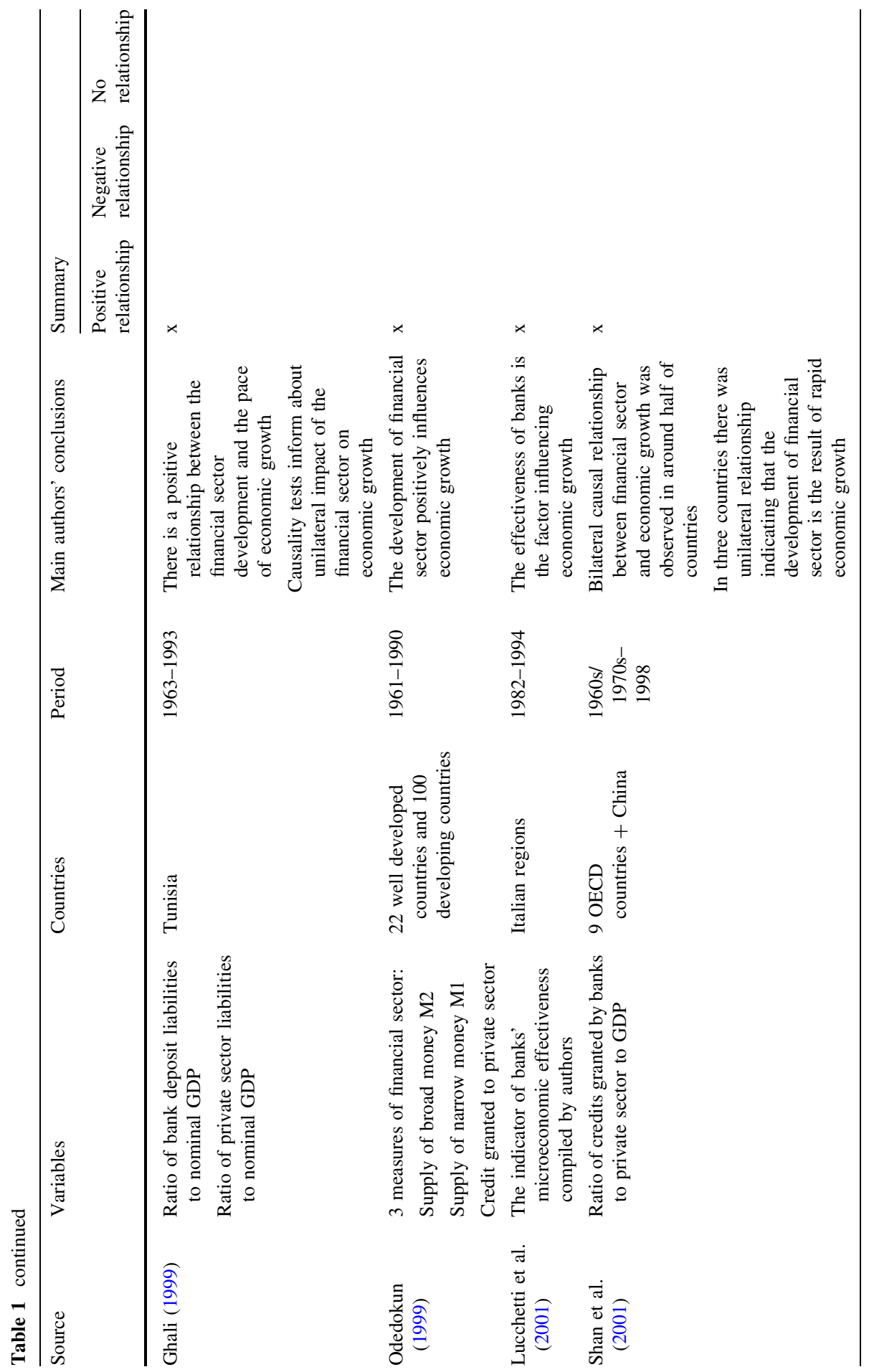




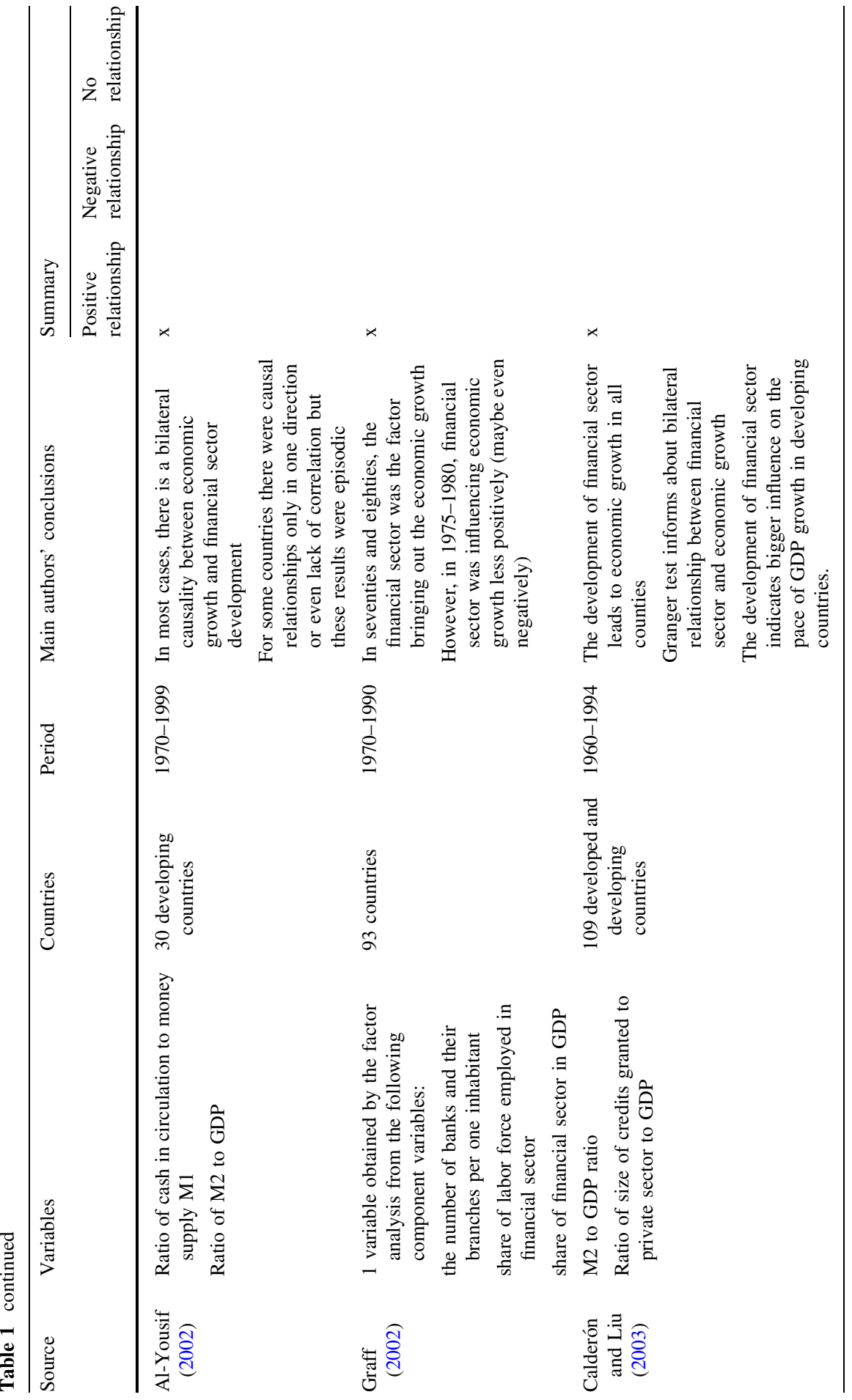




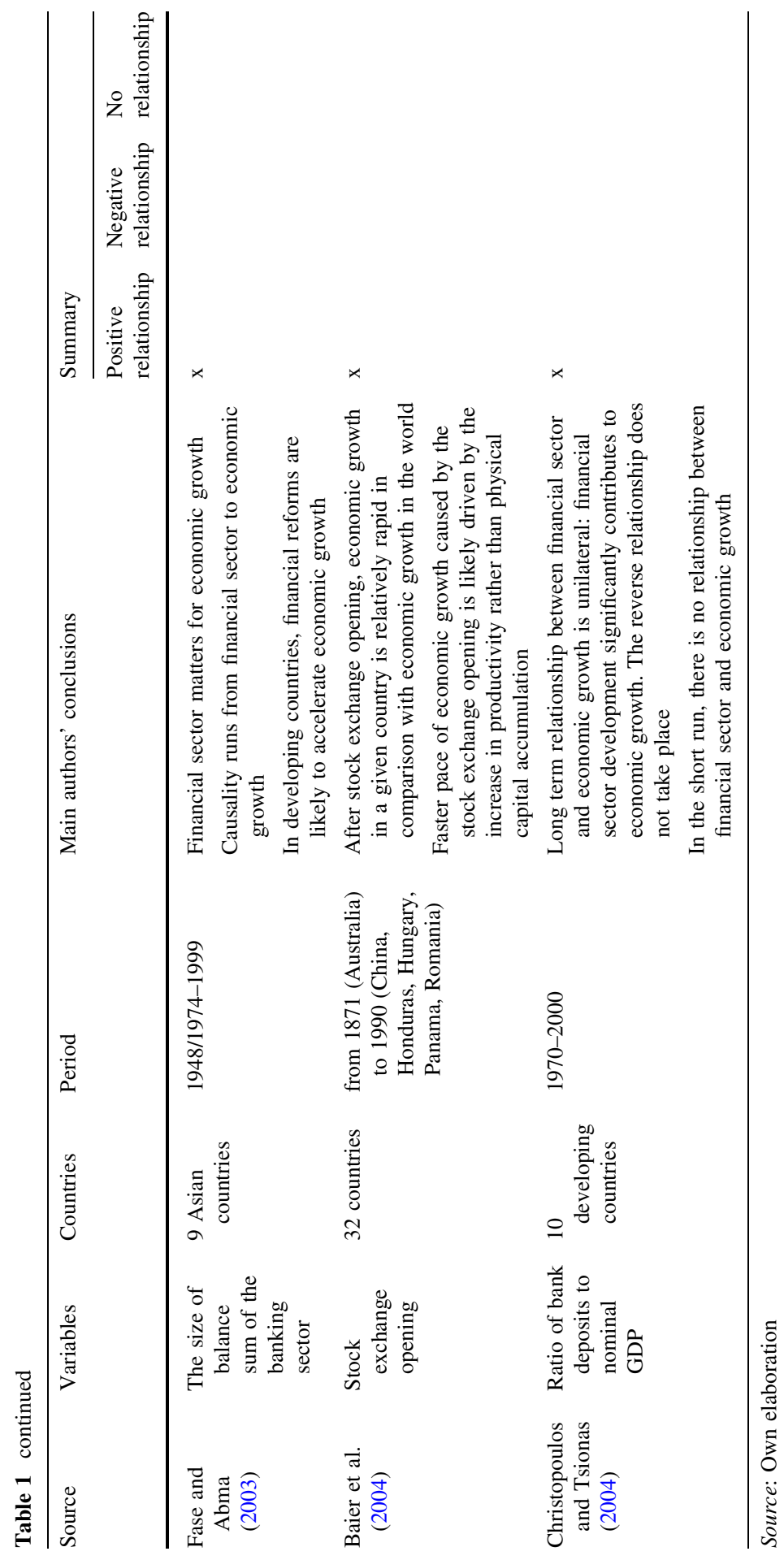


the sample of countries and time period, and the main authors' conclusions. As we can see, the contents of the individual studies are very differentiated. The authors use numerous proxies for the financial sector development. The analyses also differ in terms of the sample of countries and time period. However, regardless of these differences, all the studies indicate a positive relationship between financial sector development and economic growth as the last column in Table 1 indicates.

In Table 1 attention can be directed to the study by De Gregorio and Guidotti (1995) for 132 countries and the 1950-1985 period. The authors verify the empirical relationship between long-run growth and the degree of financial development, proxied by the ratio of bank credit to the private sector as a fraction of GDP. The authors find that this variable has a positive sign and is statistically significant in growth regressions on a large cross-country sample, but in a smaller group of Latin American countries it has a negative sign. According to the authors, the efficiency of investment (not its volume) is the main channel of transmission from financial development to growth.

The research conducted by Odedokun (1996) for the group of 71 less developed countries (LDCs) includes the variable: current liabilities to nominal GDP (in some cases the ratio of M2 to GDP). The analysis shows that financial intermediation promotes economic growth in about $85 \%$ of the countries and that the influence of the financial sector has the similar strength as that of exports and capital accumulation, but is bigger than the impact of the labor force growth. Additionally, the author also proves that the growth-promoting effects of financial intermediation are more predominant in low-income than in high-income LDCs.

Lucchetti et al. (2001) suggested a new indicator for the level of development of the banking system, based on a measure of bank microeconomic efficiency. They conducted the research for different regions of Italy in the period between 1982 and 1994. They prove that the effectiveness of banks is the factor positively influencing economic growth.

Baier et al. (2004) examine the relationship between economic growth and the development of institutions that support the financial sector. Their analysis involves the creation of a stock exchange and includes a longer time period than the majority of the other studies. The authors find that economic growth accelerates relative to the rest of the world after the opening of the stock exchange. Empirical evidence indicates that increased growth of productivity is the primary channel according to which a stock exchange increases the growth rate of output; accumulation of physical capital plays less important role. The authors also state that financial deepening is rapid before the creation of a stock exchange and slower subsequently.

We showed above a wide literature review on the issues regarding the stability of the financial sector and the impact of the financial sector development on economic growth, but the discussion of these issues is thus by no way closed. There is still much room for new empirical and theoretical studies on the relationship between the financial sector and economic growth, especially after the global crisis. 


\section{Data and methodology}

To analyze the impact of the financial system on economic growth we use the socalled Barro regression (Barro and Sala-i-Martin 2003). In more detail, the estimated regression equations have the following general form:

$$
\begin{aligned}
g \_g d p_{i t}= & \alpha_{0}+\alpha_{1} g d p \_i n i t i a l_{i t}+\alpha_{2} f i n \_d e v_{i t}+\alpha_{3}\left(f i n \_d e v_{i t}\right)^{2}+\beta_{0} \text { crisis } \\
& +\beta_{1} x_{1 i t}+\cdots+\beta_{n} x_{n i t}+\theta_{i}+\varepsilon_{i t} .
\end{aligned}
$$

The explained variable $g \_g d p$ is the growth rate of real GDP per capita at purchasing power parity (PPP). gdp_initial is the initial log GDP per capita level. This variable represents the impact of initial conditions on the subsequent rate of economic growth and appears in each estimated regression equation. The inclusion of initial GDP per capita allows us to verify the existence of conditional $\beta$ convergence hypothesis ( $\beta$ convergence takes place if less developed countries grow faster than more developed ones; the process is conditional because the regression equation includes also the other factors of economic growth that affect the steady-states of the individual countries). As the process of conditional $\beta$ convergence is largely confirmed in the studied groups of countries, the lack of this variable would result in a considerable omitted variable bias. fin_dev is the financial sector development (stability) variable. As we test the nonlinear impact of the financial system on economic growth, the squared form of this variable, $\left(f i n \_d e v\right)^{2}$, also appears in the regression equations. $x_{1}-x_{n}$ are the other economic growth determinants that are included from the chosen set of potential growth factors. $\theta_{i}$ is the individual country effect while $\varepsilon_{i t}$ is the random factor.

When estimating the regression equation given by (1), there are some problems related e.g. to the fact that some variables (like initial GDP per capita) are endogenous. Given the autoregressive character of the model, a proper method of estimation is necessary. Firstly, classical estimators as fixed or random effects are inconsistent, however, if model (1) is transformed to the following form:

$$
\begin{aligned}
g d p \_ \text {final }_{i t}= & \alpha_{0}+\left(1+\alpha_{1}\right) g d p \_i n i t i a l_{i t}+\alpha_{2} f i n \_d e v_{i t}+\alpha_{3}\left(f i n \_d e v_{i t}\right)^{2}+\beta_{0} \text { crisis } \\
& +\beta_{1} x_{1 i t}+\cdots+\beta_{n} x_{n i t}+\theta_{i}+\varepsilon_{i t} .
\end{aligned}
$$

an instrumental variables approach can be used. The model (2) is equivalent to the formula (1). The only difference is that the coefficient standing on initial GDP per capita in Eq. (2) is the $\beta$-convergence coefficient augmented by 1 . So, to obtain the standard coefficient on initial income level in the untransformed $\beta$-convergence regression, where the growth rate is the explained variable, it is necessary to subtract 1 from the coefficient $\left(1+\alpha_{1}\right)$ in model (2). However, model (2) can be estimated using the instrumental variables method or-more frequently-the generalized method of moments. The most popular estimator from the latter group is the Blundell and Bond's GMM system estimator (Blundell and Bond 1998). It is free from some weaknesses of the previously widely used Arellano and Bond (1991) estimator, like-in the case of the latter-the strong bias in small samples, especially in the case of strong autoregression of the $\beta$-type convergence models (see for 
example Goczek and Witkowski 2015, for more discussion and applications). Taking into account the above problems, in this study we apply the Blundell and Bond's GMM system estimator.

We consider the following six variables that measure the degree of financial development and stability: (1) domestic credit provided by financial sector (\% of GDP) [cred_by_fin], (2) bank nonperforming loans to total gross loans (\%) [nonp_loans], (3) bank capital to assets ratio (\%) [cap_asset], (4) market capitalization of listed companies (\% of GDP) [mar_cap], (5) turnover ratio of stocks traded (\%) [stock_turn], (6) the monetization ratio (broad money as \% of GDP) [money]. The list of the variables has been chosen on the basis of the literature review presented in the previous section.

The choice of variables to the analysis should be also placed in a broader area of what aspects of financial sector are included. We follow up the analysis carried out by Amable (2003) who analyzed the varieties of capitalism in different countries. His analysis covers five domains, including product market competition and financial systems. In general, he divided the factors that affect product market competition between inputs and outputs (Amable 2003, p. 115-116). Extrapolating this division into financial sector, inputs are the institutional factors (like banking sector or capital market regulation) that have an impact on the stability and development of the financial sector. In this study, we analyze the variables that can be rather treated as outputs of the financial sector. Amable (2003, p. 143) distinguishes the following aspects of the financial system: the sources of funds, the development and dynamics of financial markets, corporate governance, and the development of venture capital. The variables included in our analysis refer to the first two areas: the sources of funds as well as the development and dynamics of financial markets.

In this study, we consider the impact of both the level and the change in a given financial sector variable on economic growth. In the case of the change in a given variable, only a linear impact is tested without the term $\left(f i n \_d e v\right)^{2}$ in the regression equation.

Table 2 shows basic descriptive statistics for the six financial variables. It includes - for each analyzed country - the average value as well as the fifth and ninety-fifth centile of distribution of a given variable in a given country. To make the values in the table consistent with the adopted approach of data transformation, the respective centiles and mean values are calculated on the basis of 3-yearaveraged data included in the regression equations (to avoid data redundancy, the statistics for 5-year-averaged data are not reported in the table).

The variable crisis is the dummy variable representing the impact of the global crisis. It takes the value of 1 for all the subperiods that include the year 2009 and 0 otherwise.

As regards the other economic growth determinants, denoted as $x_{1}-x_{n}$, the following variables are included: (1) inflation rate (\%) (infl); (2) population growth (\%) (pop_gr); (3) investment rate (\% of GDP) (inv); (4) fertility rate (births per woman) (fert); (5) life expectancy at birth (years) (life); (6) the share of population aged 15-64 (\% of total population) (pop_15_64); (7) the openness rate (the sum of exports and imports divided by GDP) (open); and (8) government consumption 


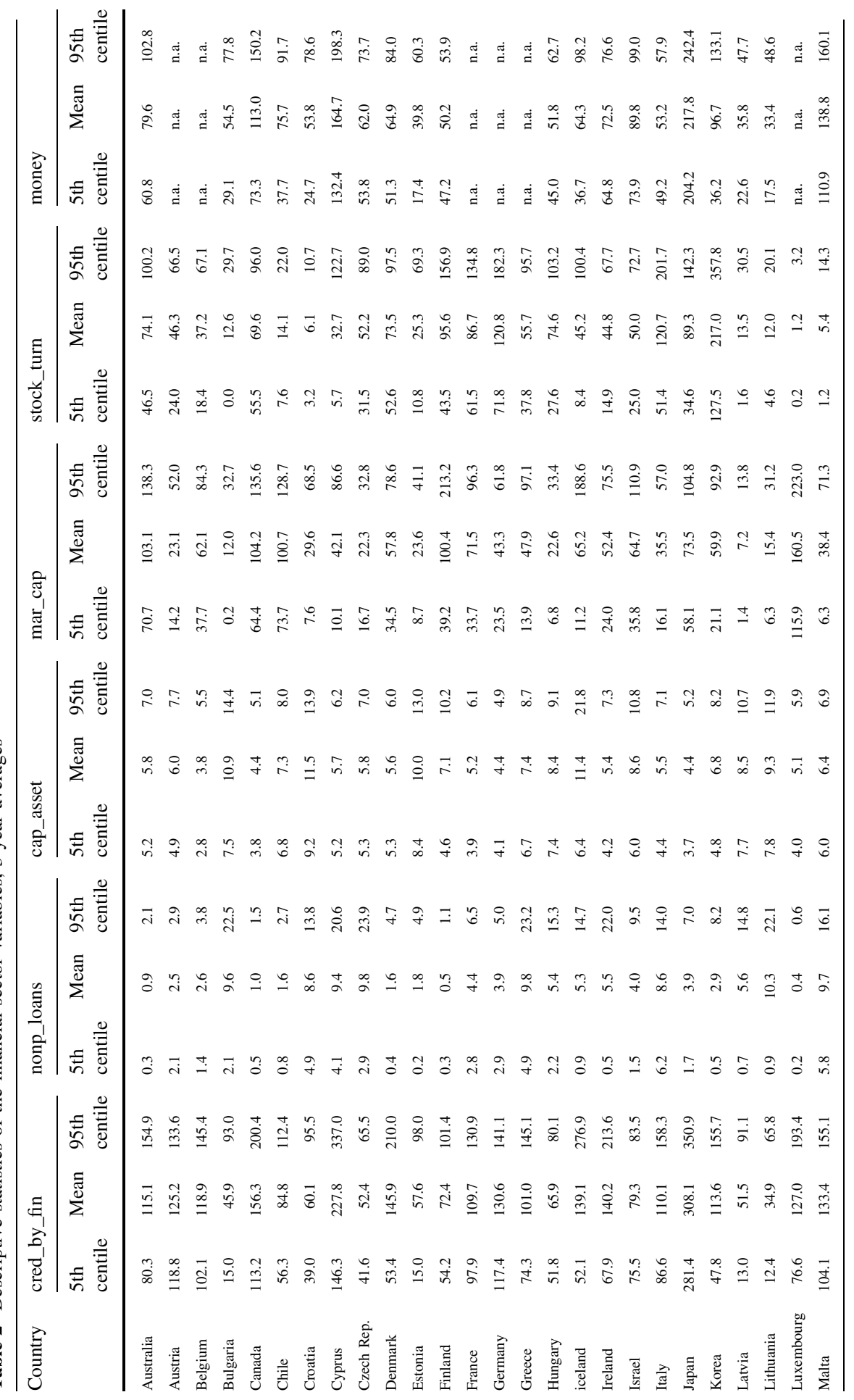




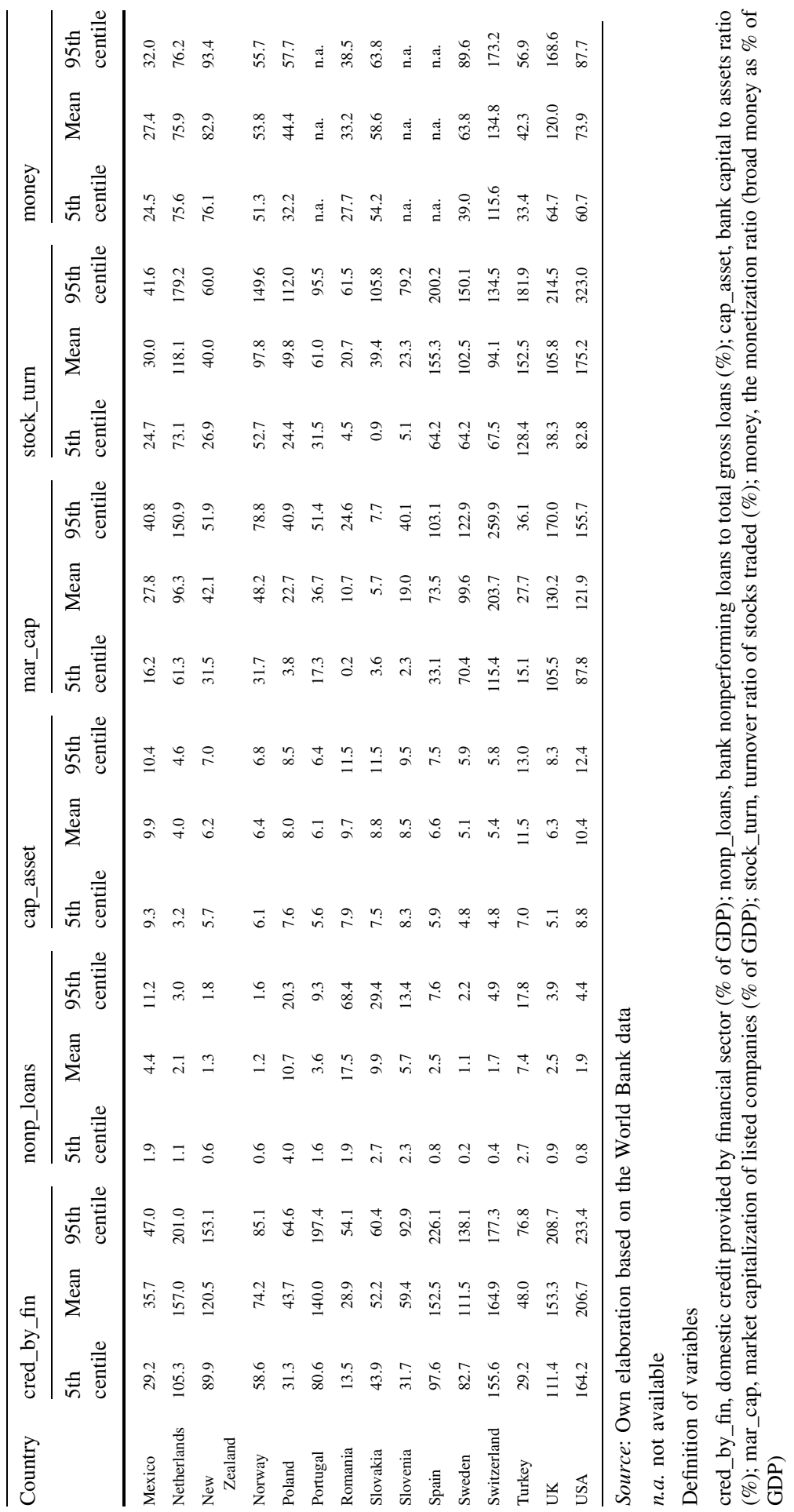

\section{Springer}


expenditure (\% of GDP) (gov_cons). The list of the above variables is in line with the economic theory and the empirical evidence on the factors that are most important in affecting economic growth, but to some extent it also reflects the authors' point of view on the subject.

Such an approach to include a fixed set of explanatory variables in one regression equation is not the only possible solution. There are a lot of studies, including our own papers (see. e.g. Próchniak and Witkowski 2013a, b), where the Bayesian Model Averaging (BMA) method was applied to the set of explanatory variables. ${ }^{3}$ Under such an approach, there are estimated all the possible combinations of the regression equations from the initially selected set of explanatory variables. The pseudo- $t$ statistics are then calculated and the statistical validity is assessed based on these pseudo- $t$ statistics that refer to a huge number of equations. Such an approach is more robust to the omitted variables' error as it is possible to include more explanatory variables in the analysis. In this paper, we build on the results of our earlier studies where we used the BMA technique to assess the significance of the individual control factors. For example, the variables which are included here as control factors turned out to be statistically significant in one of our earlier studies in which the BMA approach was adopted. ${ }^{4}$ In our opinion, to verify the research hypotheses it is not necessary to carry out the BMA procedure again.

The applied estimation technique, i.e. Blundell and Bond's GMM system estimator, requires the division of the set of explanatory variables into three groups: endogenous, predetermined, and strictly exogenous variables. Taking into account the economic theory and the results of the authors' earlier studies on the subject (see e.g. Próchniak and Witkowski 2013a), we assume that all the macroeconomic variables, including the variables that show various components of GDP or those related to monetary and fiscal policies, are endogenously given. So the following variables are endogenous: initial GDP per capita, financial sector variables, inflation rate, investment rate, the openness rate, and government consumption expenditure. The variables related to population (population growth, fertility rate, life expectancy, and the share of population aged 15-64), as well as the dummy variable (crisis) are exogenous.

The study covers the 1993-2013 period (although for some variables the analyzed period is shorter) and covers two groups of countries: (1) 28 EU member

\footnotetext{
3 For example, Białowolski et al. (2014) apply the Bayesian Averaging of Classical Estimates (BACE) method under which there are estimated all the possible combinations of regression equations for an initially selected set of explanatory variables with the OLS estimator. These authors use as an alternative the atheoretical approach in estimating empirical models of economic growth.

4 See: Próchniak and Witkowski (2013b, p. 18). In the BMA model with five control factors $(\bar{s}=5$ in the cited paper), inflation, investment, and openness rates as well as government consumption are statistically significant with $p$ value of 0.000 ; population growth, fertility rate, and life expectancy are statistically significant at the 10-percent significance level; population aged 15-64 is statistically significant at the 15-percent significance level. The cited study refers to the sample of post-socialist countries; however, in the case of many variables the results are similar in the other authors' studies where BMA model was applied to the EU countries (see e.g. Próchniak and Witkowski 2013a, 2014).
} 
states (EU28), (2) 34 OECD countries. ${ }^{5}$ The calculations are based on two groups of countries to make the results robust to the chosen sample of countries.

To exclude the impact of short-term cyclical fluctuations, being the effect of various temporal shocks, both internal and external, caused by demand-side and supply-side factors, the time series have been transformed into subperiod-average panel data. To be robust in the selection of the duration of each time interval, we consider both 3- and 5-year time spans. The levels of the financial sector development variables as well as the other economic growth determinants are taken as the average values over the years covered by a given subperiod. GDP growth rate and the changes of the financial sector development variables are calculated as the difference between the last year of the given subperiod and the last year of the previous subperiod (in the case of GDP growth rate the values were further divided by the number of years to represent annual growth rates). Initial GDP per capita is the natural logarithm of the GDP per capita level from the last year of the previous subperiod.

To increase the statistical correctness of the model but also to exclude the impact of the ex ante division of the whole period into the individual subperiods, we consider the so-called 'moving' panel data with overlapping subperiods. For example, in the case of 5-year subperiods, the consecutive observations cover the years 1994-1998, 1995-1999, 1996-2000 and so on. The inclusion of the 'moving' panel does not imply data redundancy because GDP per capita from a given year is used only twice in the calculations of final time series: once as the initial GDP per capita and once as the final GDP per capita. For example, since the growth rate for the period 1995-1999 is calculated as $(1 / 5) \times\left(\log \mathrm{GDP}_{1999}-\log \mathrm{GDP}_{1994}\right)$, then the 1999 GDP per capita is used once to calculate the 1995-1999 growth rate (as the final value) and once to calculate the 2000-2004 growth rate (as the initial value).

To account for autocorrelation, Arellano and Bond tests for first- and secondorder autocorrelation in the first-differenced errors were performed for each regression equation. The null hypothesis in this test is no autocorrelation of the given order. For the model of interest to be valid, there cannot be second-order autocorrelation (while the first order of autocorrelation is not an issue given the fact that the equation is in first differences and the first order autocorrelation of $\Delta \varepsilon$ stems directly from the non-zero variance of $\varepsilon$, while the second order autocorrelation in $\Delta \varepsilon$ would imply the first order autocorrelation in $\varepsilon$ and, as a result, inconsistency of the GMM estimator in the used form). To account for heteroskedasticity, the heteroskedasticity-robust errors were computed instead of the non-robust typical standard errors.

\footnotetext{
5 All the calculations are carried out on the full sample of countries. The EU28 group includes the following countries: Austria, Belgium, Bulgaria, Croatia, Cyprus, Czech Rep., Denmark, Estonia, Finland, France, Germany, Greece, Hungary, Ireland, Italy, Latvia, Lithuania, Luxembourg, Malta, Netherlands, Poland, Portugal, Romania, Slovakia, Slovenia, Spain, Sweden, UK. The OECD group includes the following countries: Australia, Austria, Belgium, Canada, Chile, Czech Rep., Denmark, Estonia, Finland, France, Germany, Greece, Hungary, Iceland, Ireland, Israel, Italy, Japan, Korea (South), Luxembourg, Mexico, Netherlands, New Zealand, Norway, Poland, Portugal, Slovakia, Slovenia, Spain, Sweden, Switzerland, Turkey, UK, USA.
} 
The data are mainly taken from the World Bank World Development Indicators and the IMF World Economic Outlook Databases, supplemented when necessary by the other sources (OECD and Eurostat).

\section{Results}

The results of the analysis are given in Tables 3, 4, 5, 6, 7, 8 and Figs. 1, 2, 3, 4, 5, 6. The tables show estimations of the regression equations where the GDP growth rate is regressed against a number of factors, including a variable representing financial sector and several variables treated as economic growth determinants. For each variable of interest, eight regression models were estimated. The respective models differ in the following areas: a way of data transformation (3- and 5-year overlapping panel data), the sample of countries (EU28 and OECD economies), as well as the method of how a financial sector variable is included into the model: as a stock (level) or as a change (difference). In the case of levels, each financial variable is also included in a squared form to account for eventual nonlinearities. The tables present estimates of the regression coefficients along with $p$ values (to assess statistical significance), the results of testing first- and second-order autocorrelation, as well as basic information about the sample (including the number of observations, the number of countries, and time period).

The figures show the graphical representation of the impact of the financial system on economic growth. They include only the levels of the respective financial sector variables. To make graphical results more representative, the values of the financial sector variables plotted on the horizontal axis range between the 5th and 95th centile (this range is different for various groups of countries and that is why the functions on the figures have a different length).

Table 3 and Fig. 1 include the first variable representing the financial sector, namely domestic credit provided by financial sector (\% of GDP). The results demonstrate that the change in domestic credit is a significant factor of economic growth in the EU countries. The estimated coefficients for the variable $\Delta c r e d \_b y \_$fin are positive and statistically significantly different than zero (assuming a $5 \%$ significance level) in estimated regression equations both for 3- and 5-year data. In the case of the OECD countries, the estimated coefficients are also positive but statistically insignificant (with $p$ values at 0.277 and 0.249 respectively). It means that the increase in the volume of credit, or in the other words-credit expansion, is conducive to output growth. This result is in line with the theoretical structural model. According to the theory of economics, higher investment leads to higher output both in the short run by stimulating demand and in the long run by adding to the physical capital stock. Since credit is one of the main sources of financing investment outlays, credit expansion is naturally an important economic growth determinant. It is confirmed by the regression estimates.

However, the results included in Table 3 and plotted on Fig. 1 indicate one more important finding that can be explained on the basis of supply-side economics and that shows some constraints in the impact of credit expansion on output growth. In contrast to the change in domestic credit, the level of domestic credit is negatively 


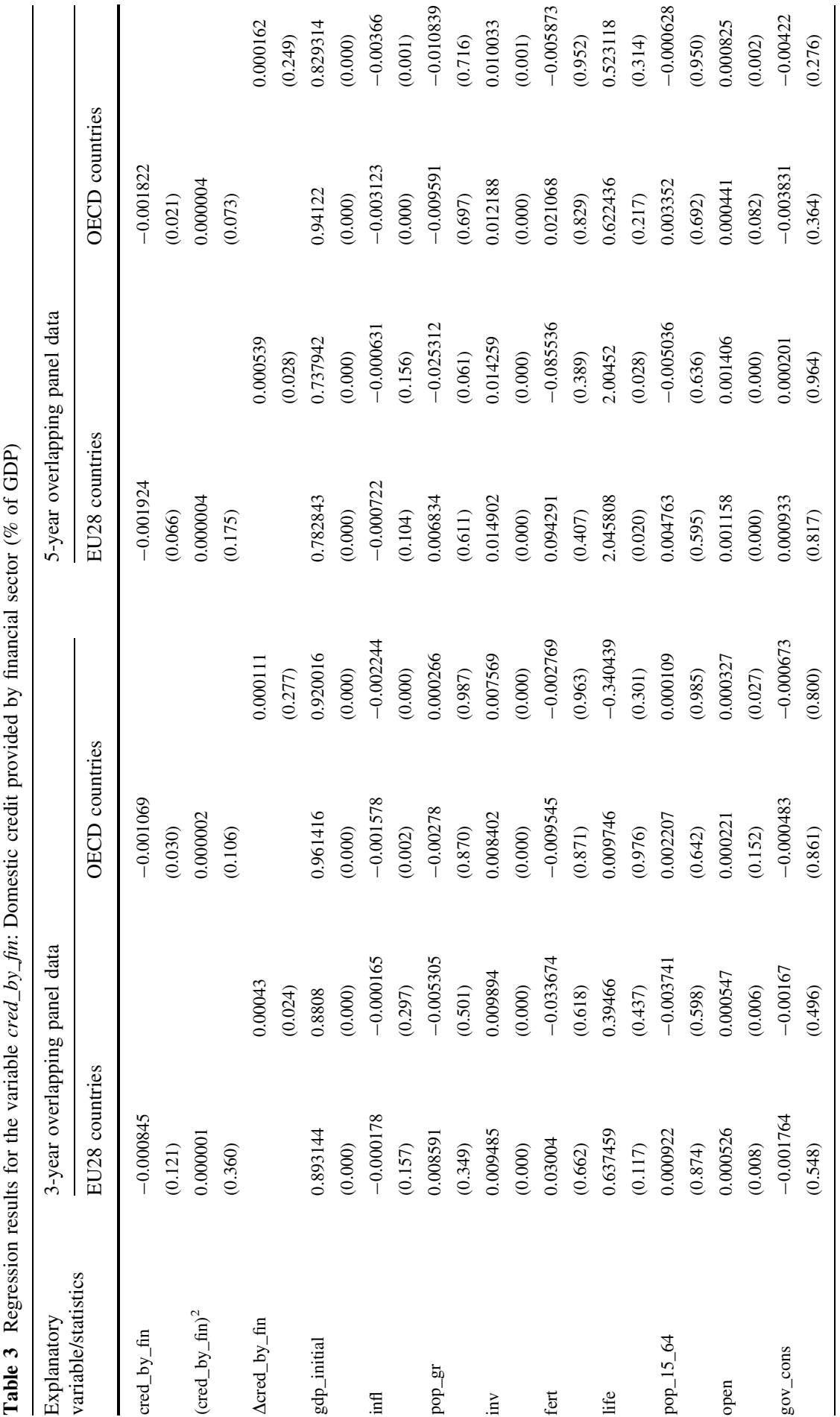




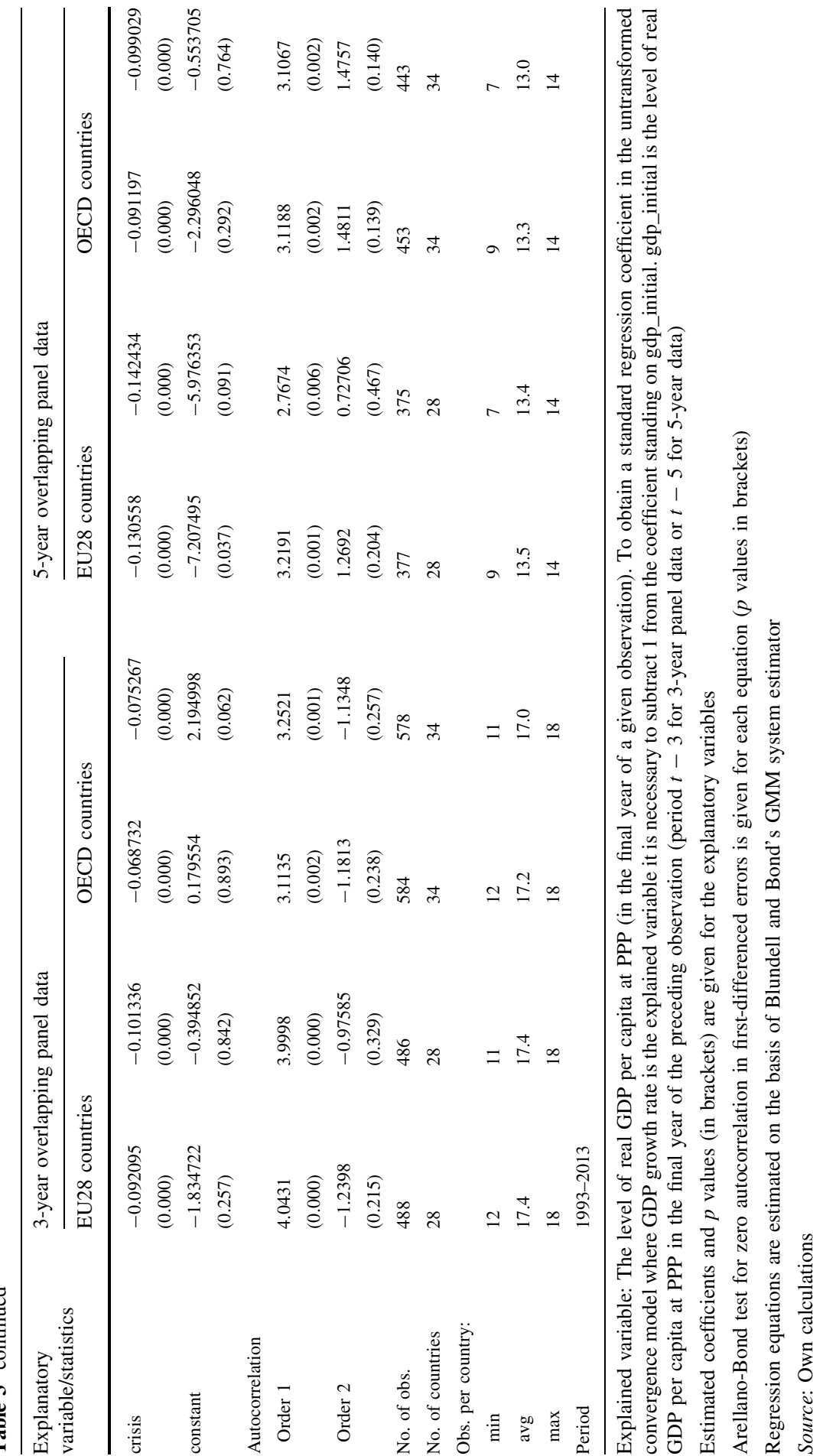




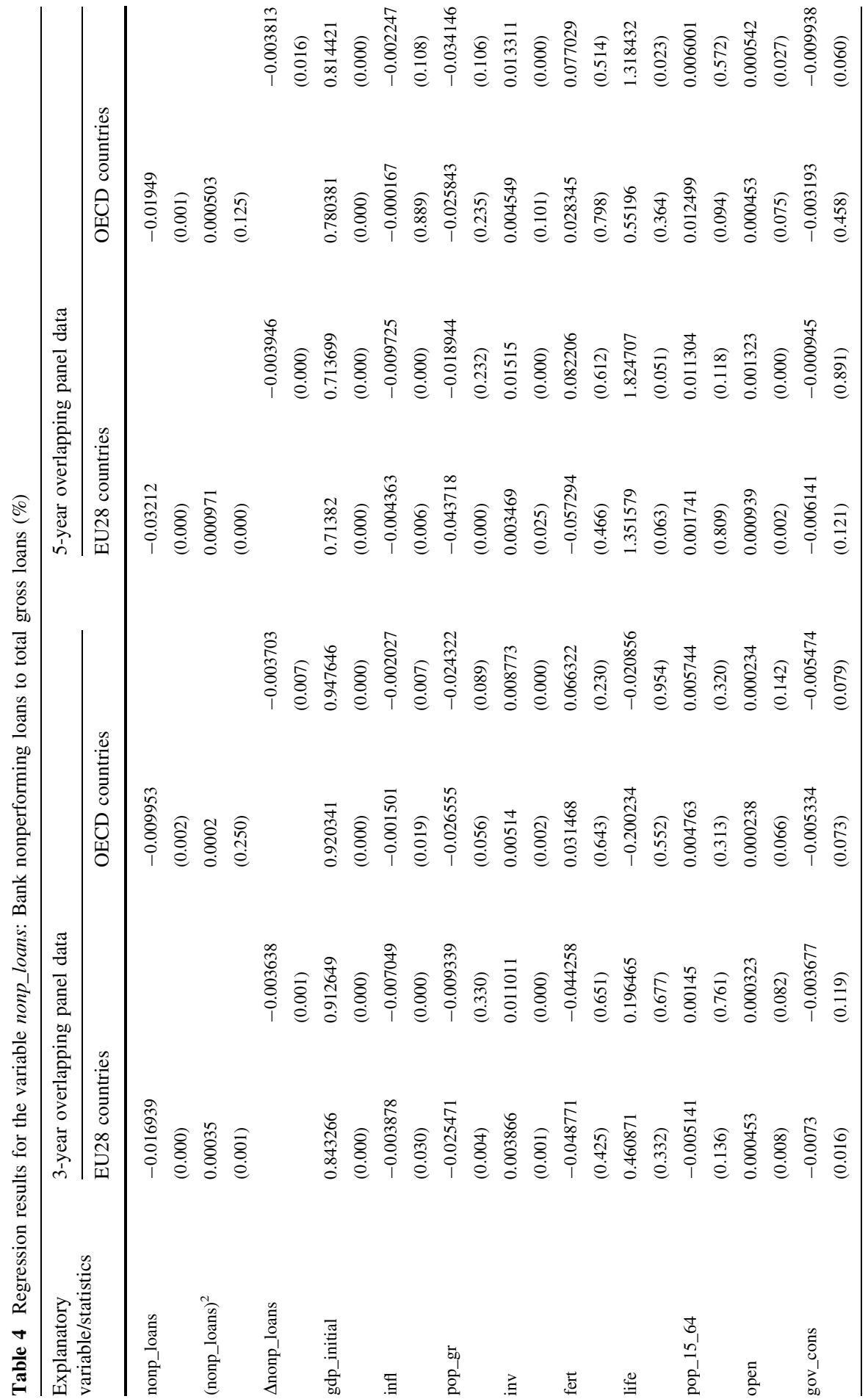




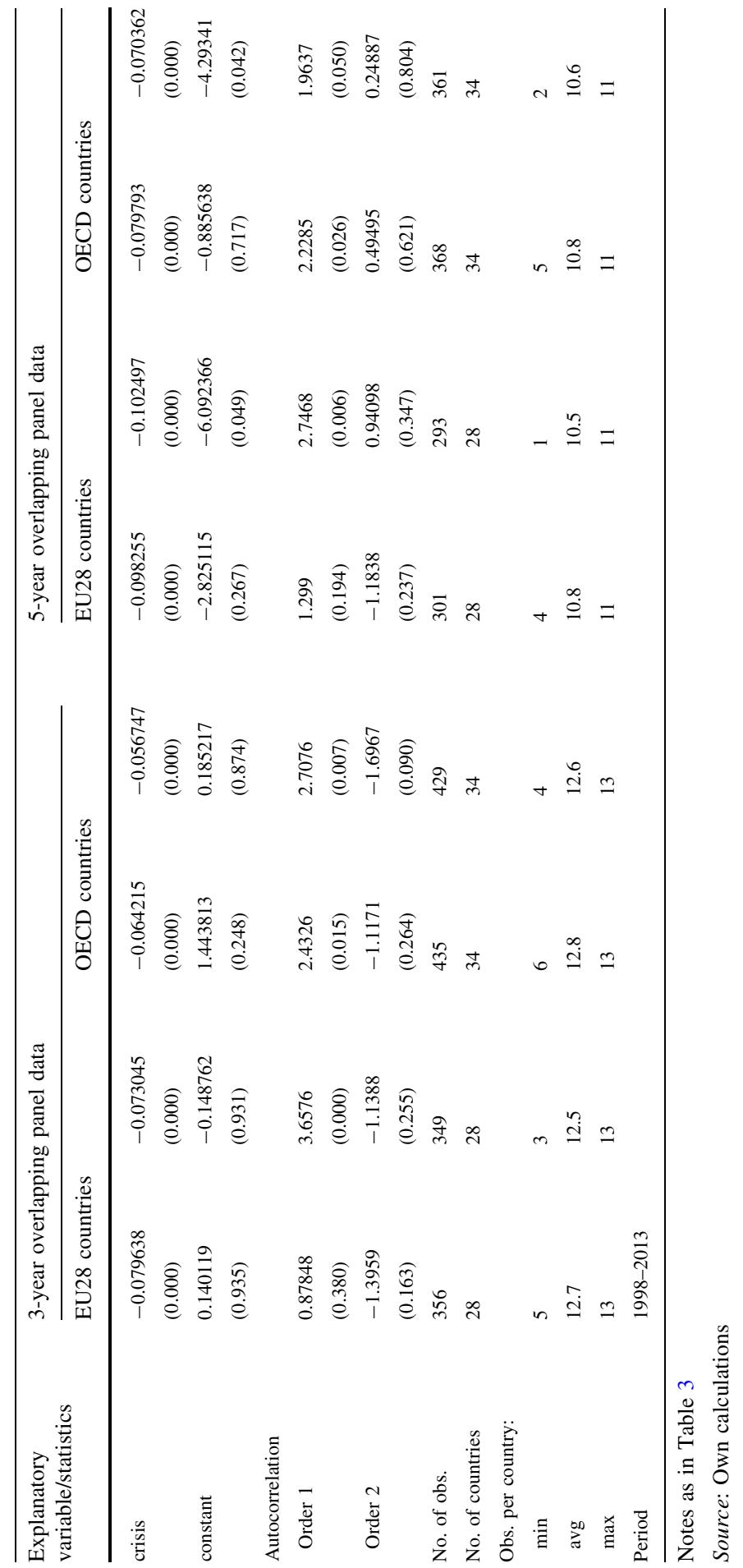




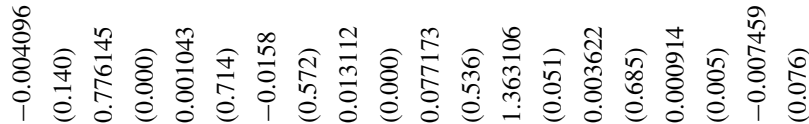

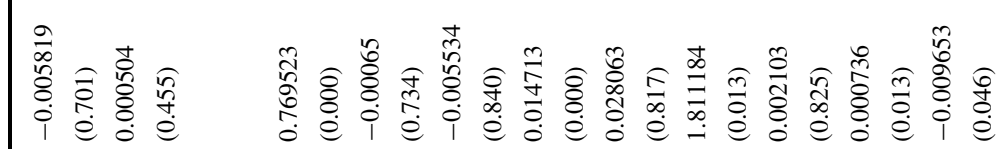

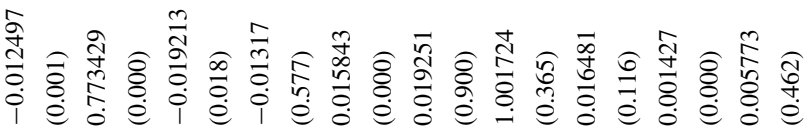

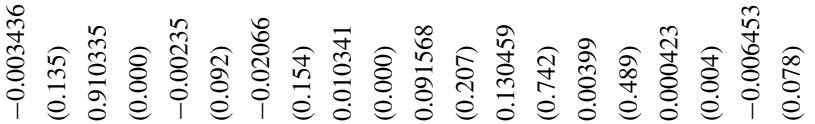

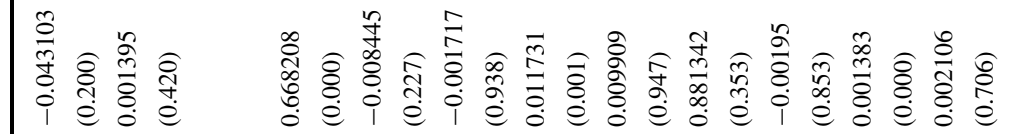




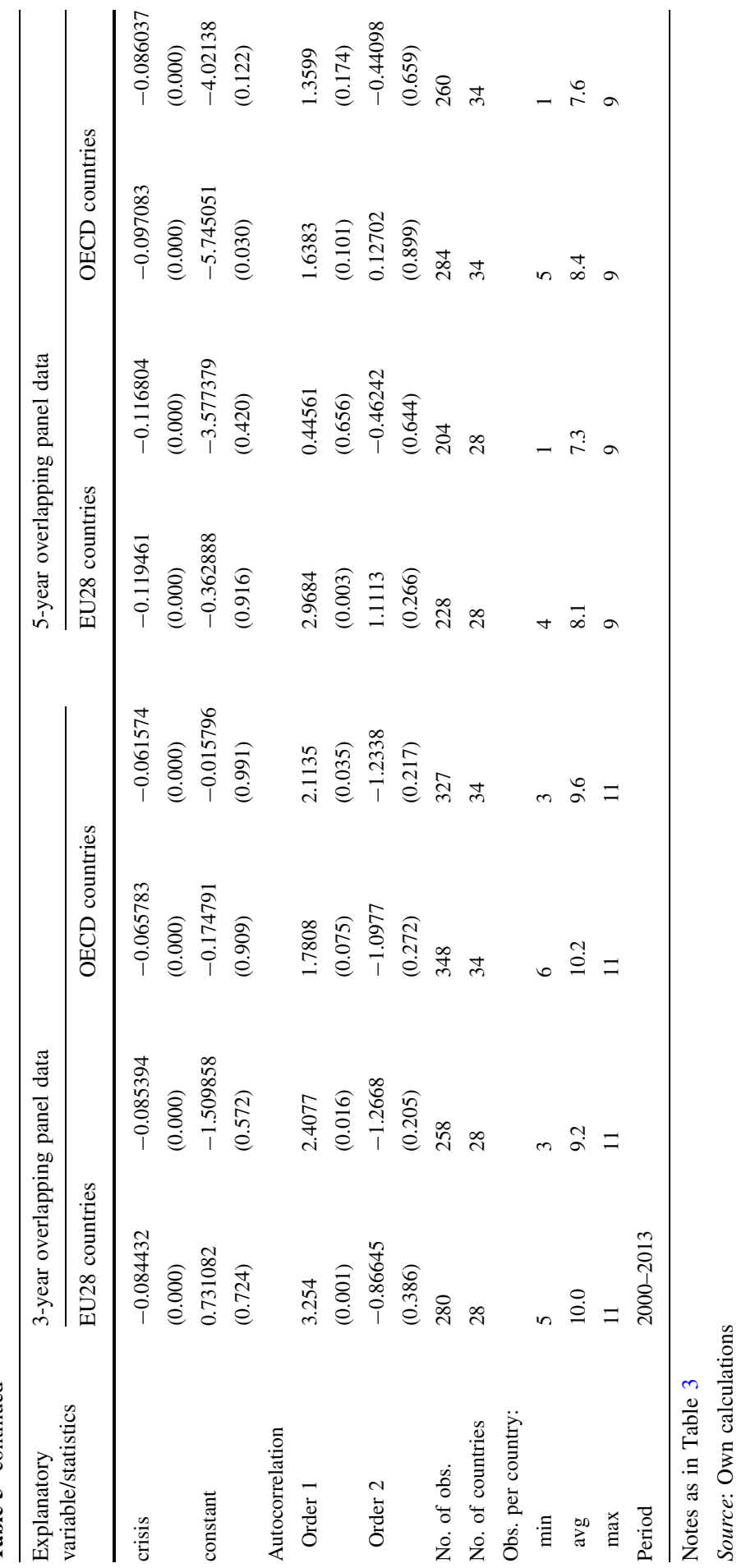




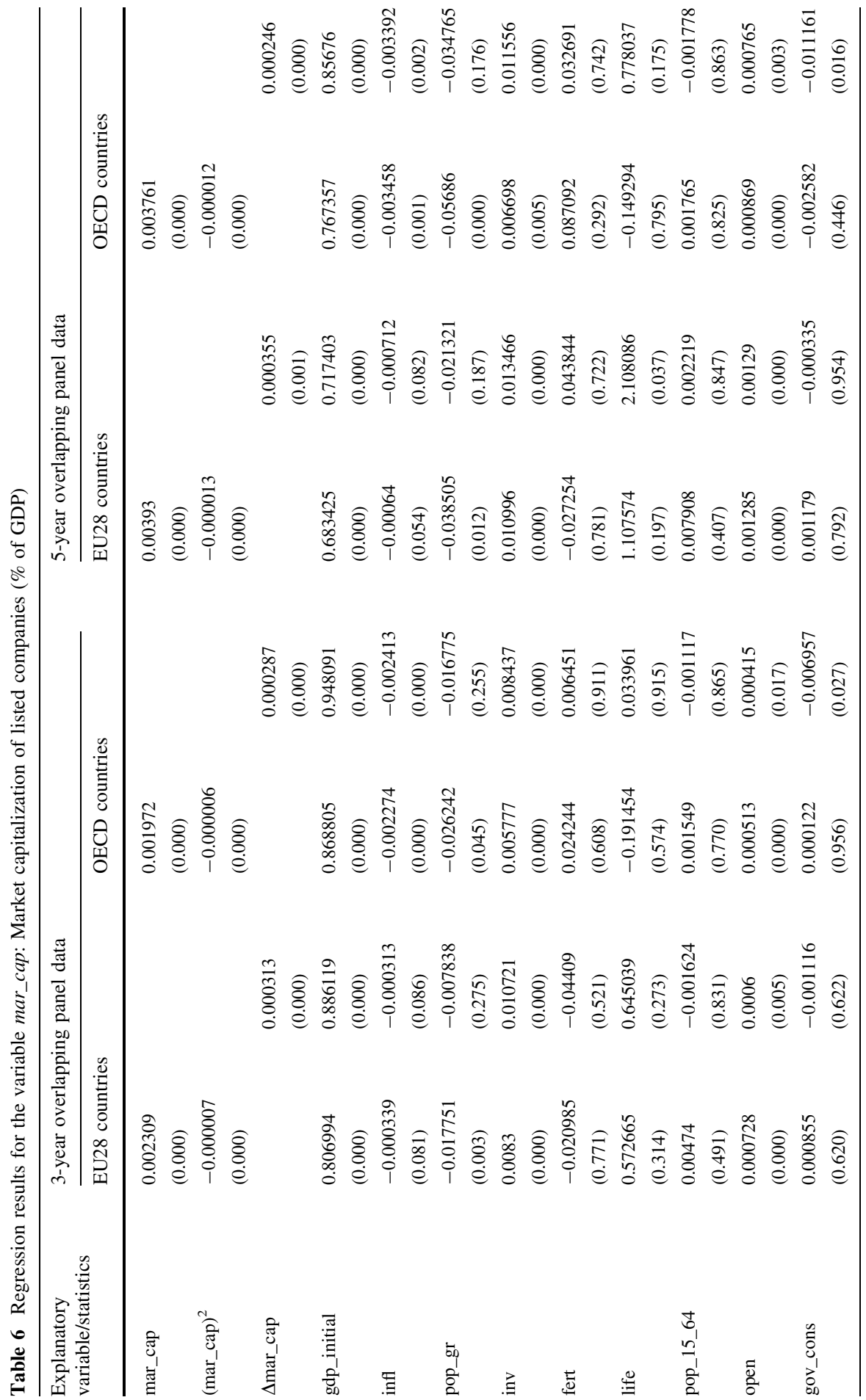




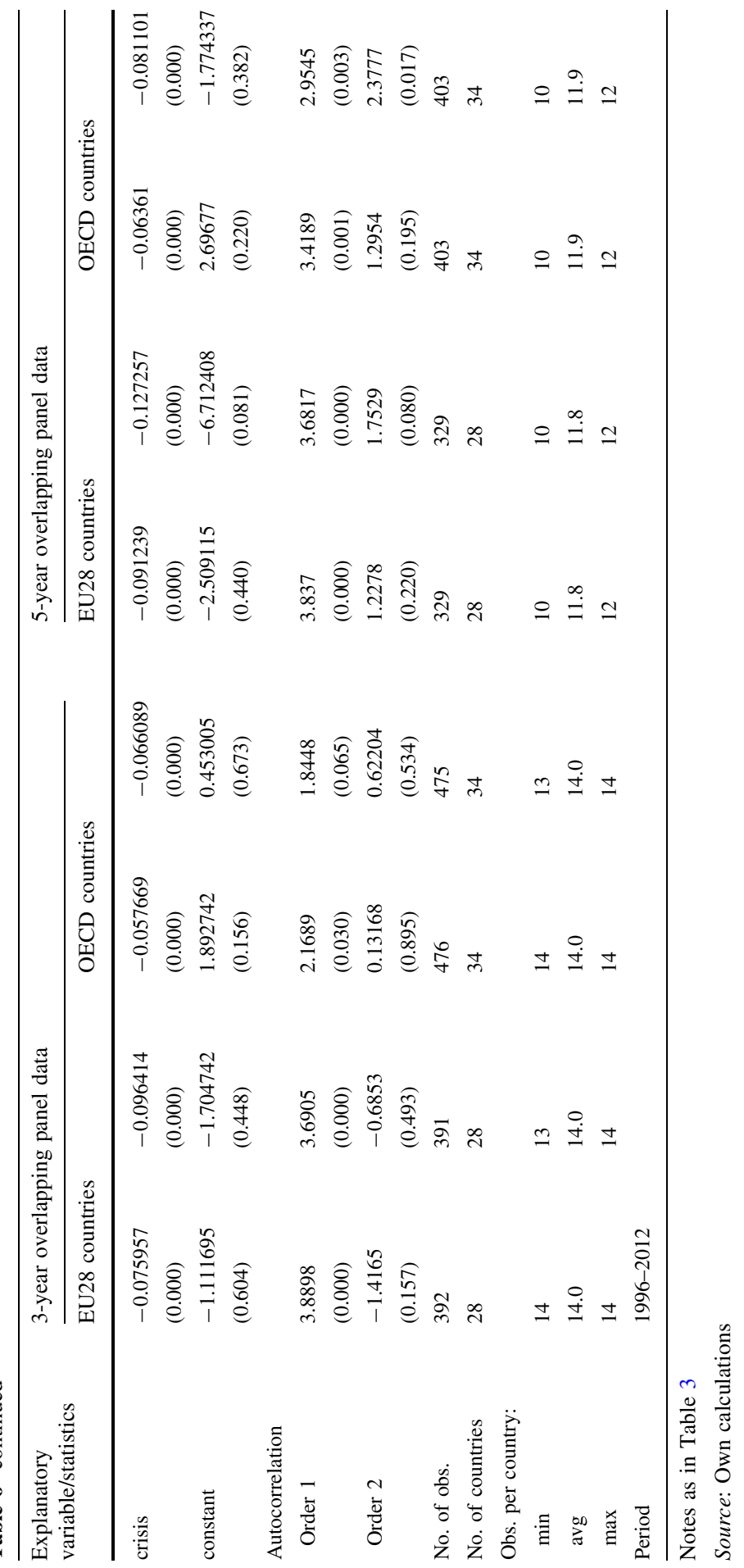




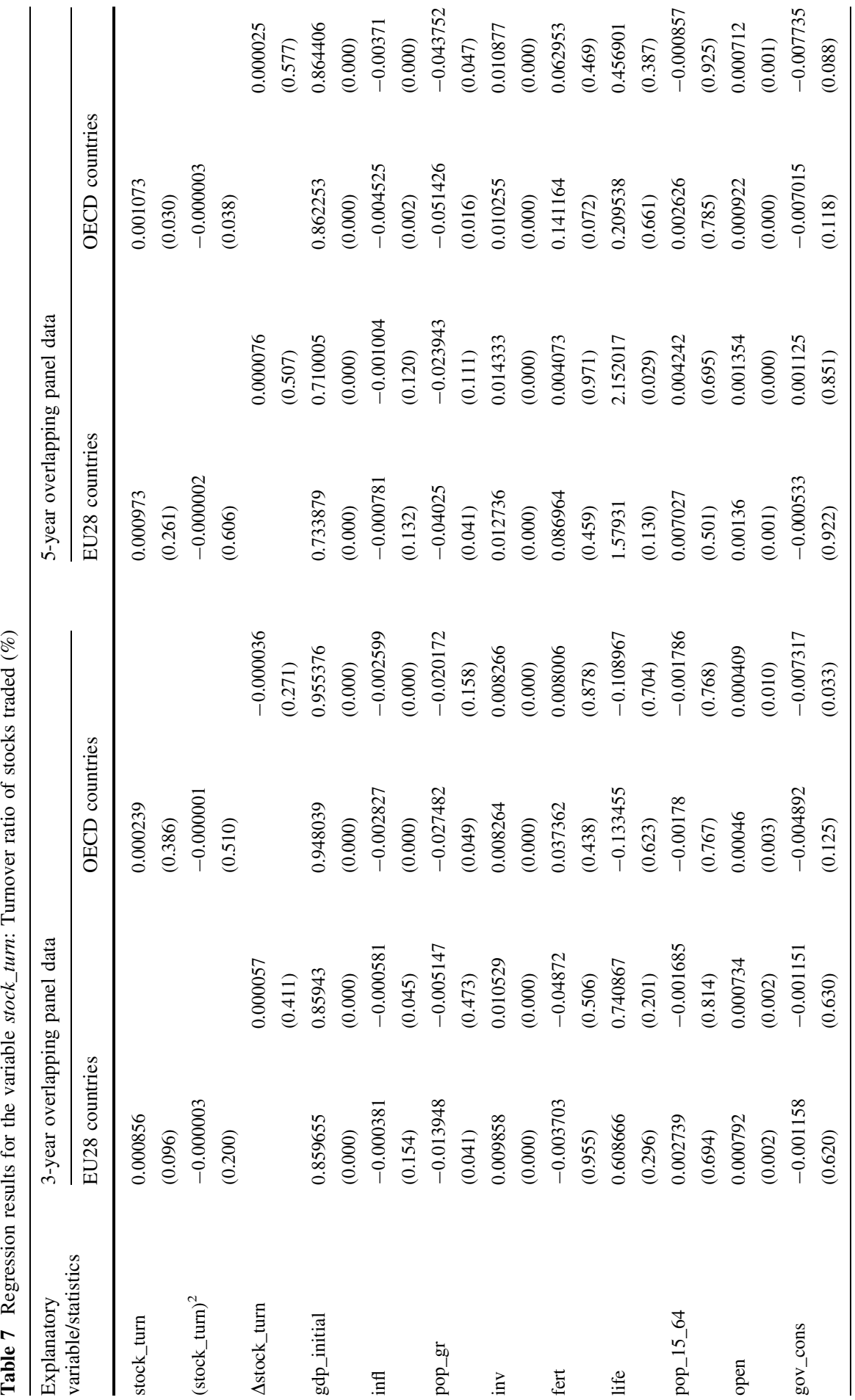




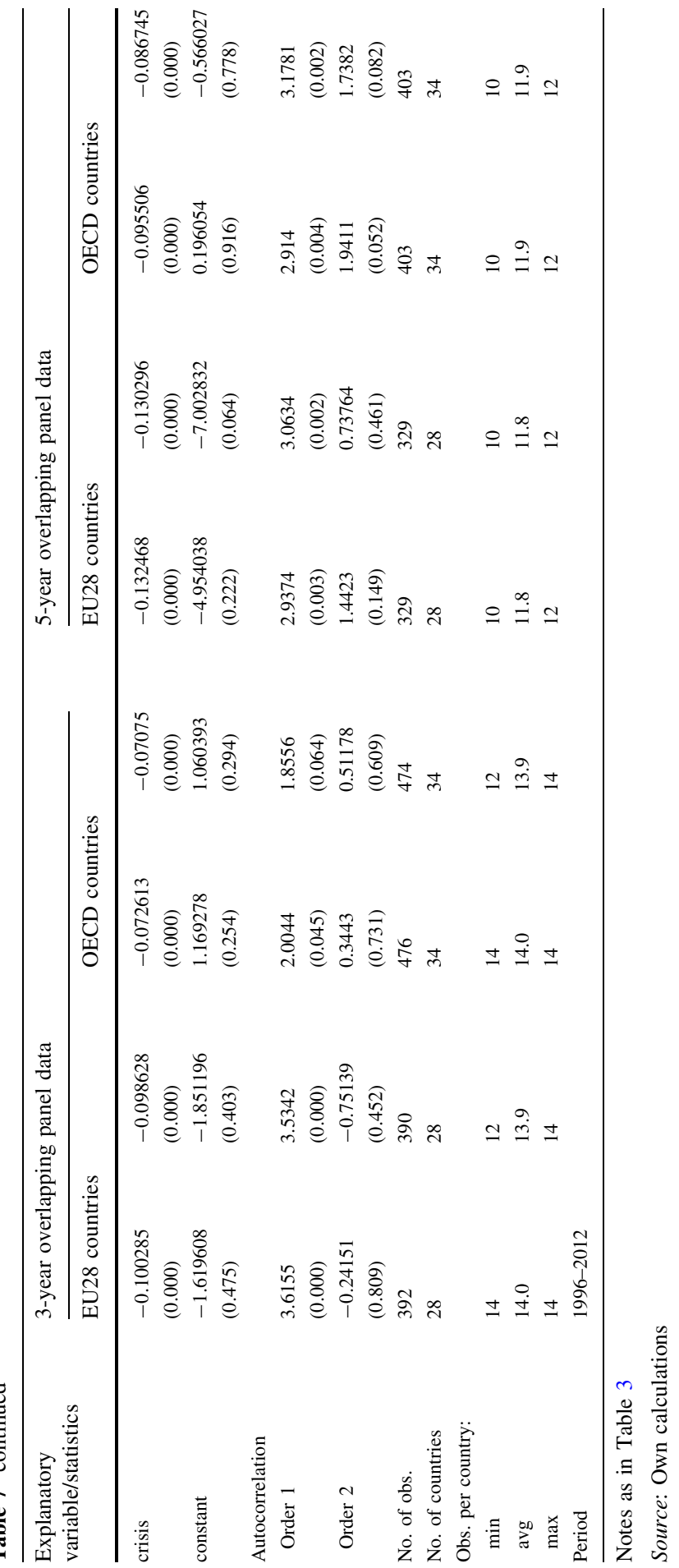


Table 8 Regression results for the variable money: Broad money (\% of GDP)

\begin{tabular}{|c|c|c|c|c|}
\hline \multirow{2}{*}{$\begin{array}{l}\text { Explanatory } \\
\text { variable/statistics }\end{array}$} & \multicolumn{2}{|c|}{ 3-year overlapping panel data } & \multicolumn{2}{|c|}{ 5-year overlapping panel data } \\
\hline & \multicolumn{2}{|c|}{ Non-euro area countries } & \multicolumn{2}{|c|}{ Non-euro area countries } \\
\hline \multirow[t]{2}{*}{ money } & -0.001087 & & -0.002403 & \\
\hline & $(0.228)$ & & $(0.168)$ & \\
\hline \multirow[t]{2}{*}{$(\text { money })^{2}$} & 0.000002 & & 0.000006 & \\
\hline & $(0.563)$ & & $(0.395)$ & \\
\hline \multirow[t]{2}{*}{$\Delta$ money } & & 0.000127 & & 0.000486 \\
\hline & & $(0.503)$ & & $(0.073)$ \\
\hline \multirow[t]{2}{*}{ gdp_initial } & 0.822432 & 0.814975 & 0.700914 & 0.707511 \\
\hline & $(0.000)$ & $(0.000)$ & $(0.000)$ & $(0.000)$ \\
\hline \multirow[t]{2}{*}{ infl } & -0.000146 & -0.000192 & -0.00077 & -0.000831 \\
\hline & $(0.297)$ & $(0.294)$ & $(0.021)$ & $(0.081)$ \\
\hline \multirow[t]{2}{*}{ pop_gr } & 0.001733 & -0.000112 & 0.017196 & 0.011291 \\
\hline & $(0.822)$ & $(0.988)$ & $(0.272)$ & $(0.469)$ \\
\hline \multirow[t]{2}{*}{ inv } & 0.010223 & 0.009685 & 0.012502 & 0.010059 \\
\hline & $(0.000)$ & $(0.000)$ & $(0.000)$ & $(0.000)$ \\
\hline \multirow[t]{2}{*}{ fert } & -0.06661 & -0.048681 & -0.123977 & -0.065034 \\
\hline & $(0.285)$ & $(0.404)$ & $(0.272)$ & $(0.489)$ \\
\hline \multirow[t]{2}{*}{ life } & 1.565448 & 1.118985 & 2.95471 & 1.808753 \\
\hline & $(0.001)$ & $(0.004)$ & $(0.000)$ & $(0.005)$ \\
\hline \multirow[t]{2}{*}{ pop_15_64 } & 0.003902 & 0.003596 & 0.005859 & 0.008351 \\
\hline & $(0.500)$ & $(0.473)$ & $(0.541)$ & $(0.385)$ \\
\hline \multirow[t]{2}{*}{ open } & 0.000281 & 0.000257 & 0.000826 & 0.00071 \\
\hline & $(0.454)$ & $(0.514)$ & $(0.255)$ & $(0.316)$ \\
\hline \multirow[t]{2}{*}{ gov_cons } & 0.004242 & 0.004522 & 0.003477 & 0.00569 \\
\hline & $(0.053)$ & $(0.039)$ & $(0.376)$ & $(0.117)$ \\
\hline \multirow[t]{2}{*}{ crisis } & -0.087215 & -0.094148 & -0.098343 & -0.103733 \\
\hline & $(0.000)$ & $(0.000)$ & $(0.000)$ & $(0.000)$ \\
\hline \multirow[t]{2}{*}{ constant } & -5.408638 & -3.440671 & -10.26859 & -5.670992 \\
\hline & $(0.001)$ & $(0.015)$ & $(0.000)$ & $(0.022)$ \\
\hline \multicolumn{5}{|l|}{ Autocorrelation } \\
\hline \multirow[t]{2}{*}{ Order 1} & 2.7004 & 2.3768 & 2.6744 & 2.2183 \\
\hline & $(0.007)$ & $(0.018)$ & $(0.008)$ & $(0.027)$ \\
\hline \multirow[t]{2}{*}{ Order 2} & -1.0981 & -0.92814 & 0.39288 & 0.21819 \\
\hline & $(0.272)$ & $(0.353)$ & $(0.694)$ & $(0.827)$ \\
\hline No. of obs. & 381 & 376 & 331 & 321 \\
\hline No. of countries & 25 & 25 & 25 & 25 \\
\hline \multicolumn{5}{|l|}{ Obs. per country: } \\
\hline $\min$ & 10 & 9 & 9 & 7 \\
\hline avg & 15.2 & 15.0 & 13.2 & 12.8 \\
\hline $\max$ & 16 & 16 & 14 & 14 \\
\hline Period & 1995-2013 & & & \\
\hline
\end{tabular}

Notes as in Table 3

Source: Own calculations 


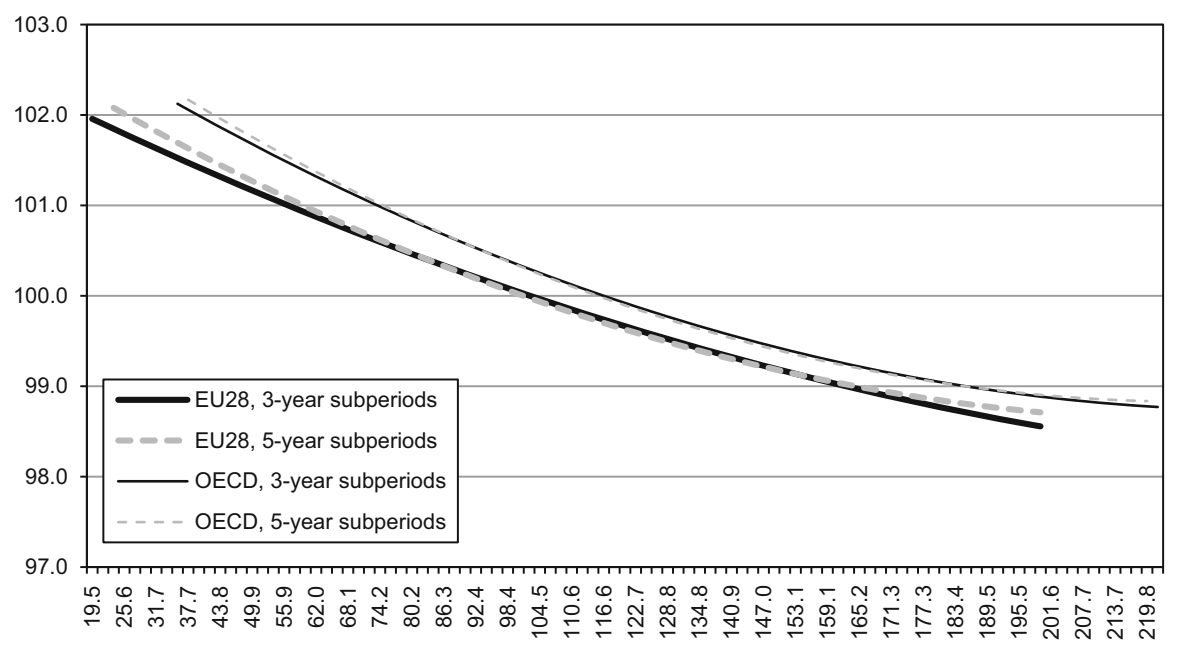

Fig. 1 The impact of domestic credit provided by financial sector (\% of GDP) on economic growth. Source: Own calculations

correlated with GDP growth in both groups of countries. Statistical significance can be verified based on information given in Table 3. It turns out that in the EU28 and OECD countries the negative coefficient standing on the cred_by_fin variable is statistically significant in all the four regression equations while the coefficient on the squared form of this variable is statistically significant only in the case of the OECD countries (assuming a $15 \%$ significance level). The direction of the relationship can only be assessed on the basis of the figure because whether the results point to a positive or negative link cannot be seen from the table since the nonlinear function is tested. In the case of a squared relationship, we deal with a parabola of which half is upward sloping and another half is downward sloping. Hence, to check the direction of the impact, it is necessary to refer to the observed values of an explanatory variable and to multiply the observed range of values by the estimated coefficients from the regression model.

Figure 1 shows that the relationship between the level of domestic credit and GDP growth is negative and reflected by convex downward sloping functions. It means that the countries that are characterized by very high volumes of domestic credit (as \% of GDP) record ceteris paribus lower GDP growth rates. At the first view, this result is in contrast with the economic theory, but after a detailed analysis it is logical and can be justified in the post-crisis period. Namely, for the last years the level of indebtedness of many countries, especially EU countries, became extremely high. Such an excessive debt surely is not a factor stimulating economic growth. For example, after a certain critical point interest on the excessive level of debt is very high and a lot of resources are devoted for repaying debt. In such a case, inputs that can be used in stimulating output growth are limited. This mechanism, strengthened by the global crisis and the crisis in the euro zone, is confirmed by our results. 


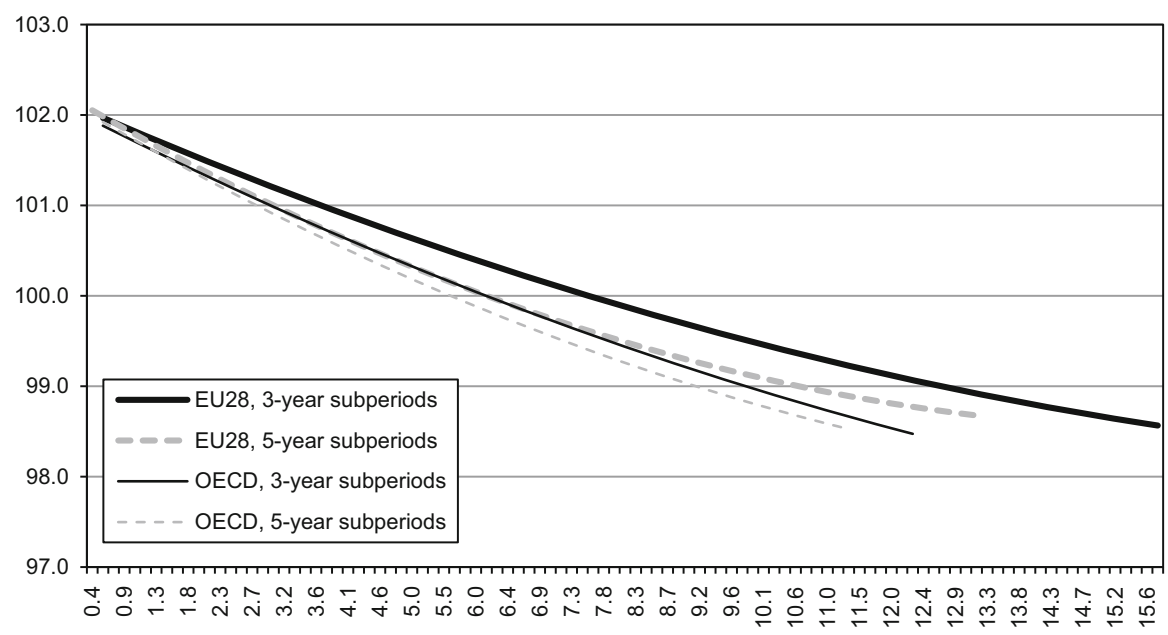

Fig. 2 The impact of bank nonperforming loans to total gross loans (\%) on economic growth. Source: Own calculations

It is also worth to refer to the current situation of some Mediterranean countries: Greece, Italy, Portugal, and Spain. The global crisis and the crisis in the euro zone both increased the level of public debt of these countries. High public debt hampers economic growth (at least, over the long run). Of course, domestic credit is not the same variable as public debt but the results can be generalized and explained in this way.

A negative impact of excessive credit on economic growth can also be explained when we refer to the values of this variable observed in the countries under study. As data in Table 2 indicate on the basis of the 95th centile of distribution of a given variable, in Japan and Cyprus, domestic credit provided by financial sector exceeds $300 \%$ of GDP; in Iceland, USA, Spain, Ireland, Denmark, UK, Netherlands and Canada, it exceeds $200 \%$ of GDP. Such a size of the financial sector is not helpful in maintaining sustainable long-term economic growth.

Hence, this study has indicated one of the channels of a negative long-term impact of the economic and financial crisis on GDP growth. Namely, excessive lending-or more general too big financial sector-may be a factor hampering the growth of output.

Table 4 and Fig. 2 show regression estimates for the second financial sector variable, namely the share of nonperforming loans in total gross loans. The theoretical structural model suggests that the impact of this variable on GDP growth should be negative. The higher the level of nonperforming loans results in the higher number of problems in the whole society and lower spending and slower output growth. This theoretical link is confirmed by our models. Table 4 and Fig. 2 demonstrate that both levels and changes in nonperforming loans negatively affect the growth rate of GDP. Almost all the coefficients for the nonperforming loans are statistically significant. Coefficient estimates for the variable $\Delta$ nonp_loans in both groups of countries are negative and statistically significantly different than zero as 


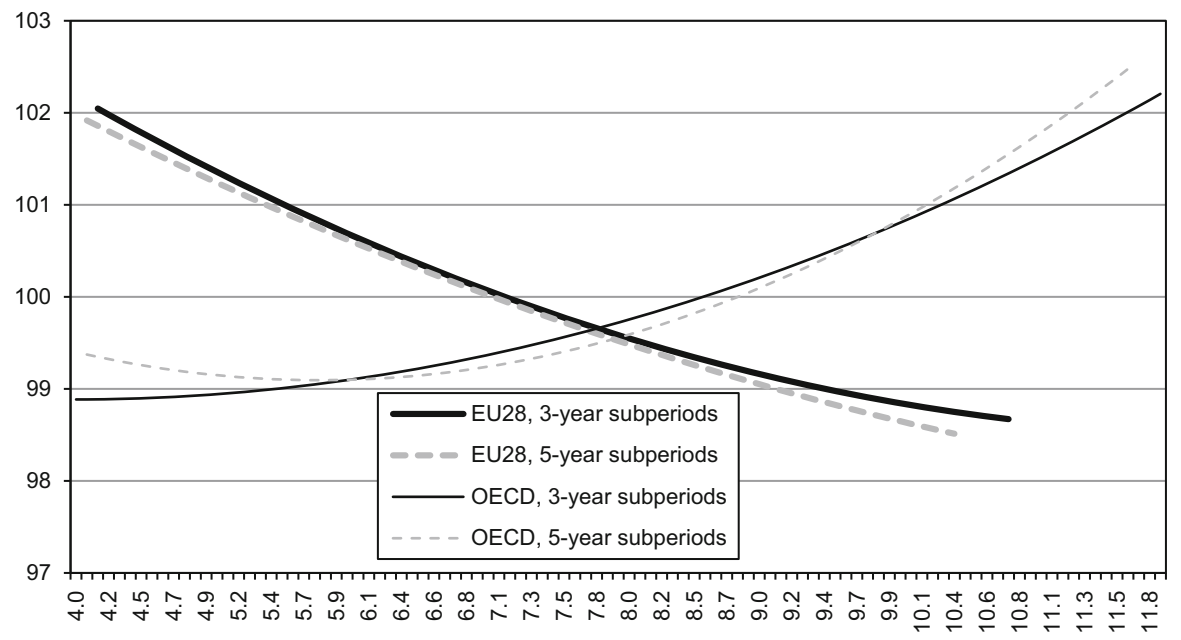

Fig. 3 The impact of bank capital to assets ratio (\%) on economic growth. Source: Own calculations

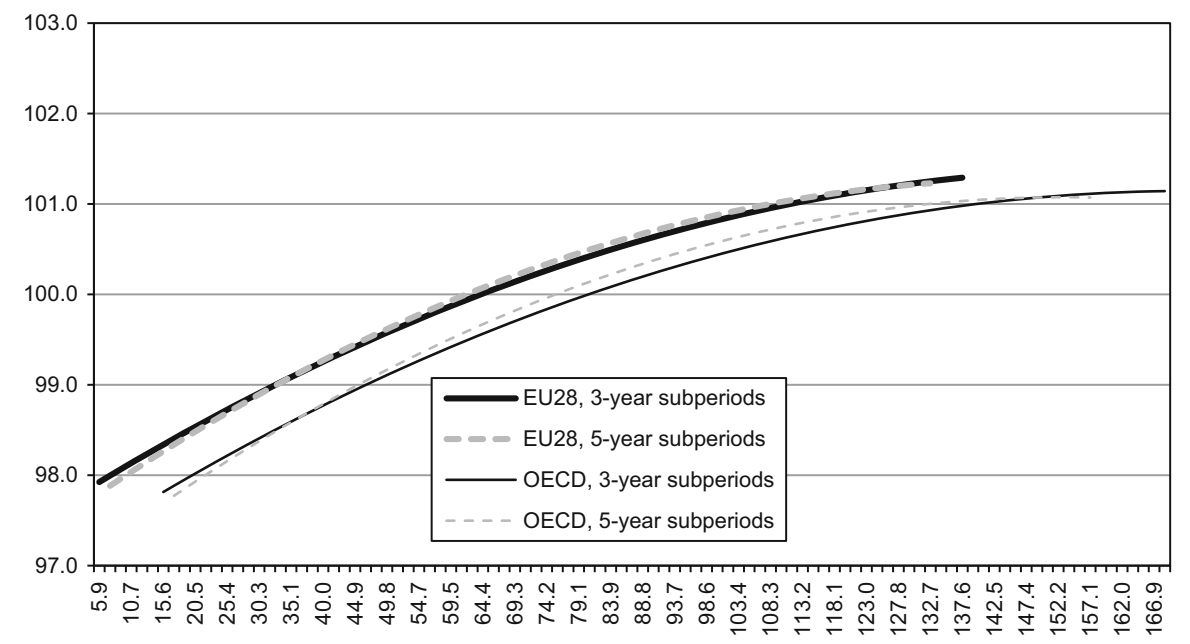

Fig. 4 The impact of market capitalization of listed companies (\% of GDP) on economic growth. Source: Own calculations

confirmed by $p$ values not exceeding 0.02 . This means that the increase in the volume of nonperforming loans negatively affects output growth. As regards the impact of the level of nonperforming loans, the relationship is also negative as confirmed by Fig. 2. Hence, the higher the level of nonperforming loans results in the slower growth rate of output. Estimated coefficients for the variable nonp_loans have $p$ values close to 0.000 meaning that at least the linear relationship is statistically significant. In the case of EU countries, the coefficient of the variable (nonp_loans) ${ }^{2}$ is also statistically significant with $p$ value not exceeding 0.001 for 


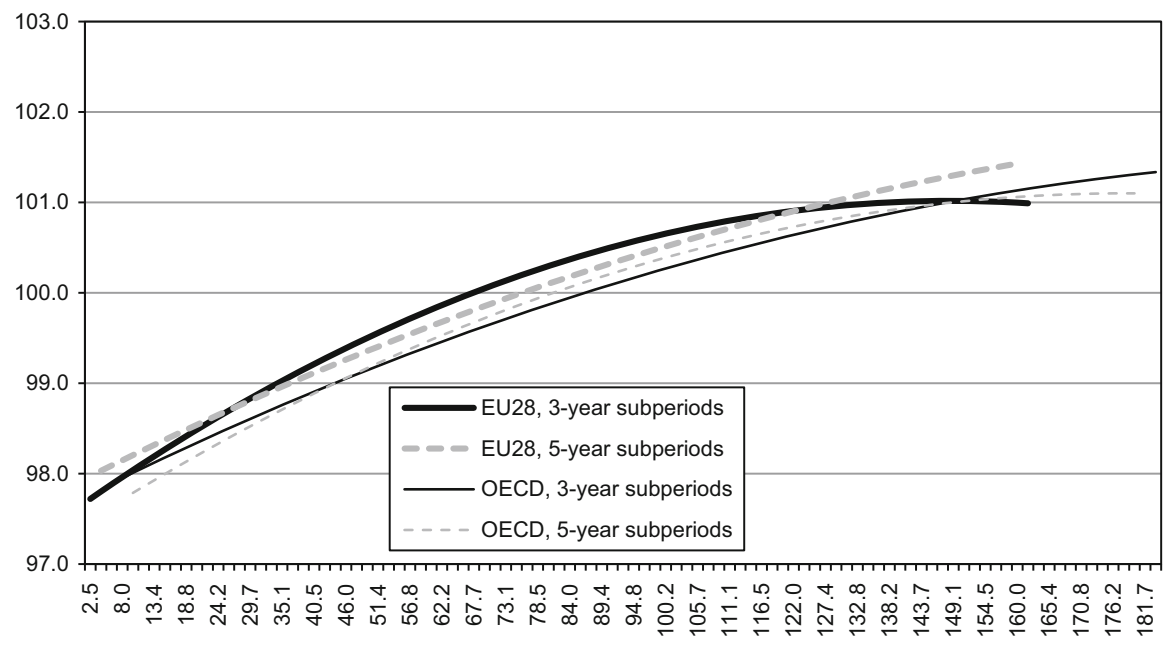

Fig. 5 The impact of turnover ratio of stocks traded (\%) on economic growth. Source: Own calculations

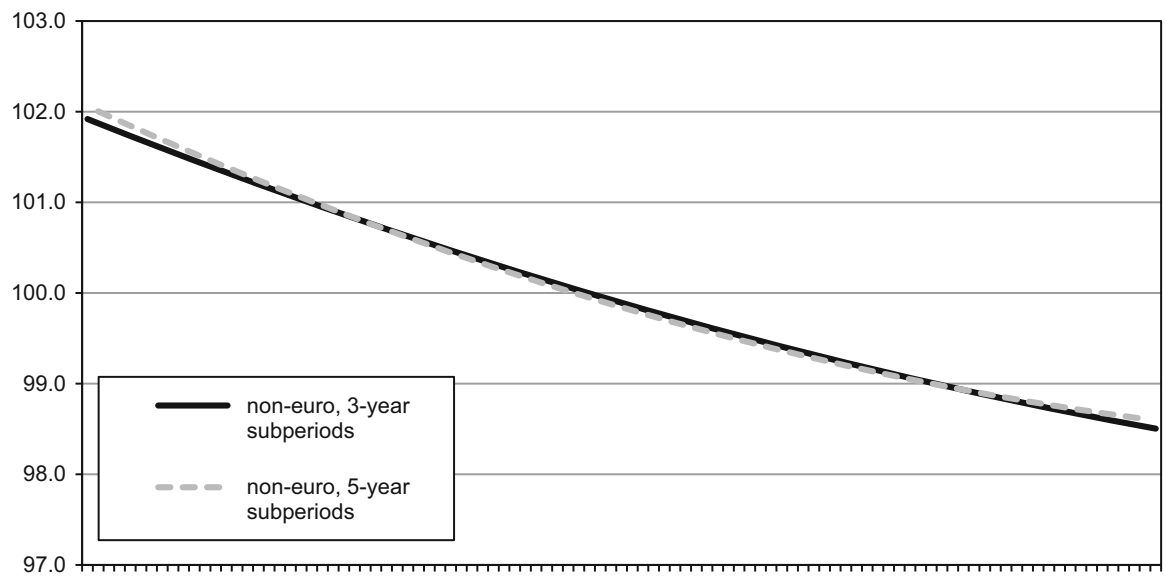

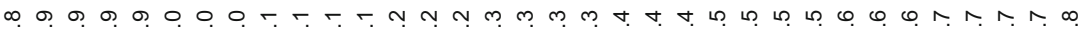
ஸे 户்

Fig. 6 The impact of broad money (\% of GDP) on economic growth. Source: Own calculations

both 3- and 5-year data pointing to a nonlinear relationship. For the OECD countries and 3-year data, the coefficient of the variable (nonp_loans) ${ }^{2}$ is insignificant ( $p$ value $=0.250$ ) meaning that the relationship is linear. Anyway, all the estimated models show a negative impact of nonperforming loans on GDP growth. This outcome is economically justified taking into account a high volume of bad loans in the analyzed countries, especially after the global crisis. In many countries under study, the ratio of nonperforming loans to total loans exceeds $20 \%$. The worst performers are: Romania, Slovakia, Czech Republic, Greece, Bulgaria, Lithuania, Ireland, Cyprus, and Poland. 
The results for the third examined variable, bank capital to assets ratio, are presented in Table 5 and Fig. 3. In the regression equations where the level of this variable is included, all the estimated coefficients for both cap_asset and $(\text { cap_asset })^{2}$ are statistically insignificant. It means that the true relationship has not been confirmed well by the model. In our opinion, the graphical representation of this relationship in Fig. 3 is mixed partly due to this insignificance. In the case of OECD countries, the impact of bank capital to assets ratio on economic growth is positive as indicated by upward sloping functions meaning that good capitalization of the banking sector is conducive to GDP growth. But in the case of the EU28 countries, the function is downward sloping which can be a spurious result, the more so that the findings are weakened by poor statistical significance of the models. However, the estimated coefficient standing for the variable $\Delta$ cap_asset is statistically significant (at $15 \%$ significance level) in all the four models but the sign of the coefficient is unexpectedly negative. It is likely that this result is spurious; however, it may also indicate the following mechanism. Namely, an increase in banks' capital (relative to assets) means a slowdown in banks' lending, which negatively affects GDP dynamics. This interpretation is supported by the results for $\Delta c r e d \_b y \_$fin variable (given in Table 3) where the models confirm that the increase in the volume of credit is a factor stimulating economic growth.

The next variable, market capitalization of listed companies (as \% of GDP), gives a lot of interesting findings as to the impact of the capital market development on economic growth. The results are given in Table 6 and Fig. 4. First, all the coefficients for this variable in any form (as level, squared level, or difference) and in any model are statistically significant (with $p$ values not exceeding 0.001 ). As regards the level of market capitalization, it turns out that the relationship is clearly nonlinear as shown in Fig. 4. All the four functions plotted on the graph are concave and have the shape of a downward sloping parabola (ending just before the peak of the parabola). It means that a positive impact is seen below a certain stage of capital market development. If stock market capitalization exceeds its critical value, there is a negative impact suggesting that further increases in market capitalization do not lead to the acceleration of output. Hence, a strong positive impact of market capitalization of listed companies on the growth rate of GDP has been evidenced for those countries and years where the level of capital market development was not excessively high. In the countries with very high capital market development, there is no room for further accelerating economic growth by increasing stock market capitalization. This is in line with the law of diminishing returns of the inputs. The highest rate of return of a given input is observed in the countries with a relatively low stock of that input. If the amount of a given input is rising, marginal product is positive but diminishing; moreover, after a certain point it can become even negative. Stock market capitalization behaves in the same way. The most beneficial effects from developing capital markets can be achieved by those countries that record a relatively low level of stock market capitalization. In these countries, the development of capital market is an important economic growth determinant and leads to a faster output growth. But in countries with well-developed capital markets, further rises in stock market capitalization are worthless in terms of output acceleration. The analysis suggests that in the countries like Switzerland, 
Luxembourg, Finland, Iceland, UK, USA and Netherlands, where stock market capitalization exceeds $150 \%$ of GDP (on the basis of the 95th centile of distribution), further developments of the stock exchange do not accelerate economic growth and under some circumstances they can be even detrimental to output dynamics.

The results for the fifth variable representing the financial system, turnover ratio of stocks traded, are given in Table 7 and Fig. 5. The data in Table 7 indicate that most of the estimated coefficients are statistically insignificant. In the case of the levels, only two models are statistically significant (at least in a linear form): for the EU countries and 3-year subperiods as well as for OECD countries and 5-year time spans. In contrast, none of the coefficients for the changes of this variable turned out to be statistically significant. Figure 5 shows an interesting outcome because the results for the turnover ratio of stocks traded are similar to those for market capitalization of listed companies. Namely, there is a positive concave relationship between turnover ratio of stocks traded and economic growth. Most of the functions in Fig. 5 finish just before the peak of the parabola. Taking into account the fact that the arguments of these functions range between the 5th and 95th centile of distribution of a given variable, it is likely that the countries in which turnover ratio is very high (mainly Korea, USA, UK, Italy, and Spain) have already exhausted the possibilities of accelerating economic growth by further expanding capital market. In summation, the results for this and the former variable show that the development of the stock exchange has a positive impact on economic growth but only until a certain point: too excessive size of capital market is not conducive to GDP growth (and may even hamper it).

The last variable of interest, broad money (as \% of GDP), gives statistically insignificant results in the regression models. The results are presented in Table 8 and Fig. 6. The number of models for this variable is reduced because measurement of the stock of money has better applications for the econometric model in the case of non-euro area countries which have their own currencies. That is why both examined groups, EU28 and OECD, were combined, then euro zone countries were removed, and the models were estimated on such a reduced sample. In the case of the level of the monetization ratio, the results based on 3- and 5-year overlapping panel data are entirely insignificant and point to a negative relationship between the monetization ratio and economic growth. It is clearly seen in Fig. 6. A negative relationship between the level of money supply and GDP growth suggests that central banks should carry out excessive monetary expansion with caution as the final effects can be opposite to the desired goals. This result is also in line with the first analyzed variable, i.e. domestic credit, which also turned out to be negatively correlated (in terms of levels) with economic growth. Statistically insignificant parameters on the money variable can also be associated with the hypothesis of the neutrality of money that is the lack of the impact of money supply on output.

The above findings are reinforced by good economic and econometric properties of the models. First of all, the models are generally correct from the econometric point of view. The remaining explanatory variables often are statistically significant (but some exceptions are present). The models do not reveal autocorrelation because 
in the tests for second-order autocorrelation $p$ values are relatively high so the null hypothesis of no autocorrelation is not rejected.

As regards economic fit, the signs of the estimated parameters for the other control variables are generally in line with the economic theory. Firstly, the models indicate the existence of $\beta$ convergence. It means that less developed countries grow faster than more developed ones. It is so because the coefficient on initial income is $<1$ implying that in the standard convergence regression where GDP growth rate is the explained variable the coefficient on initial income would be negative, pointing to a negative impact of initial GDP per capita level on subsequent economic growth. Conditional $\beta$ convergence is confirmed by numerous empirical studies and it would be atypical if our models rejected the existence of the $\beta$ convergence hypothesis.

Secondly, the models confirm a negative direct impact of the global crisis on GDP growth. The coefficient standing for the binary variable crisis is negative in all model specifications. It means that during the global crisis the rate of economic growth was on average slower than it would be prior or after the crisis if the values of control variables were the same.

Thirdly, the models indicate a negative impact of inflation on economic growth. Unlike some theoretical approaches in which inflation is favorable to economic growth, our estimations definitely show that inflation is an obstacle to achieve rapid growth of output. This finding also suggests that central banks should pursue antiinflationary policies because over a longer time period the impact of inflation on GDP growth is negative.

Fourthly, the results point to a positive impact of investment and openness rate on economic growth. While these relationships are in line with the theoretical structural model, the latter one is not always confirmed by empirical studies. This is because for many countries the degree of economic openness is rather correlated with the size of a country and not with economic growth. In contrast to this empirical evidence from the other studies, the current analysis demonstrates that the higher the openness rate, the higher the economic growth. Obtaining such a relationship may result from the fact that this study is based on data averaged over 3- or 5-year subperiods and thus it includes the medium-run relationships.

Fifthly, the impact of the government consumption expenditure on economic growth turns out to be rather negative. In opposite to some views about the beneficial effects of public spending, our models indicate that at least during the medium term higher public consumption does not lead to more rapid economic growth.

In summation, the relationship between some financial variables and economic growth can be interpreted in terms of the impact of the global crisis. For example, a negative impact of the volume of domestic credit on economic growth results partly from the fact that the global crisis strengthened some negative aspects of too big financial sector. Moreover, the global crisis increased dramatically the volume of nonperforming loans to such a size that hampers economic growth.

Finally, it is necessary to mention that all the econometric results do not imply causal relationships between a given variable and economic growth. What is tested on the basis of econometric models is coexistence rather than causality. So, it cannot be excluded that financial development reveals a bilateral causal relationship with 
economic growth or even a reverse causal link. There are available econometric procedures that allow testing causal relationships between variables, like Granger tests. However, this is a different methodology of research and it is beyond the scope of this analysis. Moreover, these tests have a lot of shortcomings. Hence, the conclusions in terms of causal links should be drawn on the basis of logical reasoning and theoretical structural model rather than formal econometric tests and such an approach is adopted in the current study.

\section{Conclusions}

The paper analyzes the theoretical and empirical relationship between the financial system and economic growth attempting to answer the question on what level of financial system development positively influences GDP dynamics and which direction should a financial system develop in order to support economic growth. A special emphasis is placed on the impact of the global crisis. The study covers the 1993-2013 period and two groups of countries: 28 EU countries and 34 OECD economies. Six variables are used to measure the degree of financial development: domestic credit provided by financial sector, bank nonperforming loans, bank capital to assets ratio, market capitalization of listed companies, turnover ratio of stocks traded, and the monetization ratio. Regression equations estimated on the basis of Blundell and Bond's GMM system estimator are used to verify the research hypotheses. A new element of the empirical analysis is the application of the extended econometric and economic modelling, including testing nonlinear relationships between financial development and economic growth, analyzing both levels and changes of the financial variables, as well as estimating the models on the basis of a moving panel with overlapping observations.

The results show that the size and the performance of the financial system have a significant impact on economic growth. However, different variables representing the financial sector yield different results in this area. In the case of some variables (e.g. stock market capitalization or turnover ratio of stocks traded), there is an evident positive and nonlinear relationship with GDP dynamics. The impact on economic growth is in line with the law of diminishing marginal returns-when a specified value of stock market capitalization or turnover ratio is reached, further development of capital market is not a factor stimulating GDP growth. In the case of some other variables (e.g. domestic credit), the results for the changes of a given variable give opposite outcomes compared to the levels of the same variable. Nevertheless, the analysis demonstrates that too big size of the financial sector, i.e. excessive lending or too high volume of nonperforming loans, has a negative impact on GDP growth.

In contrast to the other studies on the subject, this analysis yields more reliable results because many robustness tests were performed by estimating numerous regression models with different assumptions, methods, and samples of countries. Another value added of this study is the inclusion of the impact of the global crisis when assessing the relationship between the financial system and economic growth. 
Acknowledgments The research project has been financed by the National Science Centre in Poland (decision number DEC-2013/09/B/HS4/03610).

Open Access This article is distributed under the terms of the Creative Commons Attribution 4.0 International License (http://creativecommons.org/licenses/by/4.0/), which permits unrestricted use, distribution, and reproduction in any medium, provided you give appropriate credit to the original author(s) and the source, provide a link to the Creative Commons license, and indicate if changes were made.

\section{References}

Abu-Bader S, Abu-Qarn AS (2008) Financial development and economic growth: empirical evidence from six MENA countries. Rev Dev Econ 12:803-817. doi:10.1111/j.1467-9361.2008.00427.x

Ahmed SM, Ansari MI (1998) Financial sector development and economic growth: the South-Asian experience. J Asian Econ 9:503-517. doi:10.1016/S1049-0078(99)80100-6

Al-Yousif KY (2002) Financial development and economic growth. Another look at the evidence from developing countries. Rev Financial Econ 11:131-150. doi:10.1016/S1058-3300(02)00039-3

Amable B (2003) The diversity of modern capitalism. Oxford University Press, Oxford

Arcand JL, Berkes E, Panizza U (2012) Too much finance?. IMF Working Paper 12/161, International Monetary Fund, Washington

Arellano M, Bond S (1991) Some tests of specification for panel data: Monte Carlo evidence and an application to employment equations. Rev Econ Stud 58:277-297. doi:10.2307/2297968

Arestis P, Demetriades PO (1997) Financial development and economic growth: assessing the evidence. Econ J 107:783-799. doi:10.1111/j.1468-0297.1997.tb00043.x

Baier SL, Dwyer GP Jr, Tamura R (2004) Does opening a stock exchange increase economic growth? J Int Money Finance 23:311-331. doi:10.1016/j.jimonfin.2004.01.001

Barro RJ, Sala-i-Martin X (2003) Economic growth. The MIT Press, Cambridge

Bencivenga VR, Smith BD (1991) Financial intermediation and endogenous growth. Rev Econ Stud 58:195-209. doi:10.2307/2297964

Białowolski P, Kuszewski T, Witkowski B (2014) Bayesian averaging of classical estimates in forecasting macroeconomic indicators with application of business survey data. Empirica J Eur Econ 41:53-68. doi:10.1007/s10663-013-9227-x

Blanco L (2009) The finance-growth link in Latin America. South Econ J 76:224-248

Blundell R, Bond S (1998) Initial conditions and moment restrictions in dynamic panel data models. J Econom 87:115-143. doi:10.1016/S0304-4076(98)00009-8

Calderón C, Liu L (2003) The direction of causality between financial development and economic growth. J Dev Econ 72:321-334. doi:10.1016/S0304-3878(03)00079-8

Cecchetti SG, Kharroubi E (2015) Why does financial sector growth crowd out real economic growth?. BIS Working Paper 490, Bank for International Settlements, Basel

Choe C, Moosa IA (1999) Financial system and economic growth: the Korean experience. World Dev 27:1069-1082. doi:10.1016/S0305-750X(99)00042-X

Christopoulos DK, Tsionas EG (2004) Financial development and economic growth: evidence from panel unit root and cointegration tests. J Dev Econ 73:55-74. doi:10.1016/j.jdeveco.2003.03.002

Creel J, Hubert P, Labondance F (2015) Financial stability and economic performance. Econ Model 48:25-40. doi:10.1016/j.econmod.2014.10.025

De Gregorio J, Guidotti PE (1995) Financial development and economic growth. World Dev 23:433-448. doi:10.1016/0305-750X(94)00132-I

Deidda L, Fattouh B (2002) Non-linearity between finance and growth. Econ Lett 74:339-345. doi:10. 1016/S0165-1765(01)00571-7

Demetriades PO, Hussein KA (1996) Does financial development cause economic growth? Time-series evidence from 16 countries. J Econ Dyn Control 51:387-411. doi:10.1016/S0304-3878(96)00421-X

Esso LJ (2010) Re-examining the finance-growth nexus: structural break, threshold cointegration and causality evidence from the ECOWAS. J Econ Dev 35:57-80

Fase MMG, Abma RCN (2003) Financial environment and economic growth in selected Asian countries. J Asian Econ 14:11-21. doi:10.1016/S1049-0078(02)00237-3 
Friedman M, Schwartz AJ (1963) Monetary history of the United States, 1867-1960. Princeton University Press, Princeton

Ghali KH (1999) Financial development and economic growth: the Tunisian experience. Rev Dev Econ 3:310-322. doi:10.1111/1467-9361.00070

Goczek Ł, Witkowski B (2015) Determinants of card payments. Appl Econ. doi:10.1080/00036846.2015. 1102846

Goldsmith RW (1969) Financial structure and development. Yale University Press, New Haven

Graff M (2002) Causal links between financial activity and economic growth: empirical evidence from a cross-country analysis, 1970-1990. Bull Econ Res 54:119-133

Greenwood J, Jovanovic B (1990) Financial development, growth, and the distribution of income. J Polit Econ 98:1076-1107

Greenwood J, Smith BD (1997) Financial markets in development, and the development of financial markets. J Econ Dyn Control 21:145-181. doi:10.1016/0165-1889(95)00928-0

Hansson P, Jonung L (1997) Finance and economic growth: the case of Sweden 1834-1991. Res Econ 51:275-301. doi:10.1006/reec.1997.0046

Hassan MK, Sanchez B, Yu J (2011) Financial development and economic growth: new evidence from panel data. Q Rev Econ Finance 51:88-104. doi:10.1016/j.qref.2010.09.001

Ireland PN (1994) Money and growth: an alternative approach. Am Econ Rev 84:47-65

King RG, Levine R (1993) Finance and growth: schumpeter might be right. Q J Econ 108:717-737. doi: $10.2307 / 2118406$

Levine R (1997) Financial development and economic growth: views and agenda. J Econ Lit 35:688-726

Levine R (2004) Finance and growth: theory and evidence. NBER Working Paper 10766

Levine R, Zervos S (1998) Stock markets, banks, and economic growth. Am Econ Rev 88:537-558

Lucas RE (1988) On the mechanics of economic development. J Monet Econ 22:3-42

Lucchetti R, Papi L, Zazzaro A (2001) Banks' inefficiency and economic growth: a micro-macro approach. Scott J Polit Econ 48:400-424. doi:10.1111/1467-9485.00206

Marcinkowska M, Wdowinski P, Flejterski S, Bukowski S, Zygierewicz M (2014) Wpływ regulacji sektora bankowego na wzrost gospodarczy—wnioski dla Polski. Materiały i Studia no. 305, Instytut Ekonomiczny NBP, Warszawa

Matysek-Jedrych A (2007) System finansowy—definicja i funkcje. Bank i Kredyt 37(10):38-47

McKinnon RI (1973) Money and capital in economic development. Brookings Institution, Washington

Mishkin FS (2002) Ekonomika pieniądza, bankowości i rynków finansowych (przekład A. Minkiewicz). Wydawnictwo Naukowe PWN, Warszawa

NBP (Narodowy Bank Polski) (2014) Rozwój systemu finansowego w Polsce w 2013 r. Narodowy Bank Polski, Warszawa. http://www.nbp.pl/systemfinansowy/rozwoj2013.pdf. Accessed 5 July 2015

Odedokun MO (1996) Alternative econometric approaches for analysing the role of the financial sector in economic growth: time-series evidence from LDCs. J Dev Econ 50:119-146. doi:10.1016/03043878(96)00006-5

Odedokun MO (1999) How the size of the monetary sector affects economic growth: econometric evidence from industrial and developing countries. J Policy Model 21:213-241. doi:10.1016/S01618938(97)00037-9

Pietrzak B, Polanski Z, Wozniak B (2004) System finansowy w Polsce. Wydawnictwo Naukowe PWN, Warszawa

Próchniak M, Witkowski B (2013a) Time stability of the beta convergence among EU countries: Bayesian model averaging perspective. Econ Model 30:322-333. doi:10.1016/j.econmod.2012.08.031

Próchniak M, Witkowski B (2013b) Real $\beta$ convergence of transition countries. Robust approach. East Eur Econ 51:6-26. doi:10.2753/EEE0012-8775510301

Próchniak M, Witkowski B (2014) On the stability of the catching-up process among old and new EU member states. Implications from Bayesian model averaging. East Eur Econ 52:5-27. doi:10.2753/ EEE0012-8775520201

Robinson J (1952) The generalization of the general theory. In: Robinson J (ed) The rate of interest and other essays. Macmillan, London

Rodrik D (2002) Institution, integration and geography: in search of deep determinants of economic growth. https://www.sss.ias.edu/files/pdfs/Rodrik/Research/institutions-integration-geography.pdf. Accessed 30 June 2015

Rodrik D (2003) Growth strategies. NBER Working Paper 10050

Rodrik D (2004) Institutions rule: the primacy of institutions over geography and integration in economic development. J Econ Growth 9:131-165. doi:10.1023/B:JOEG.0000031425.72248.85 
Rousseau PL, Sylla R (1999) Emerging financial markets and early U.S. growth. NBER Working Paper 7448

Rousseau PL, Sylla R (2001) Financial systems, economic growth, and globalization. NBER Working Paper 8323

Sahay R, Čihák M, N'Diaye P, Barajas A, Bi R, Ayala D, Gao Y, Kyobe A, Nguyen L, Saborowski Ch, Svirydzenka K, Reza Yousefi S (2015) Rethinking financial deepening: stability and growth in emerging markets. IMF Staff Discussion Notes No. 15/8

Schumpeter J (1960) Teoria rozwoju gospodarczego. PWN, Warszawa

Shan J (2005) Does financial development 'lead' economic growth? A vector auto-regression appraisal. Appl Econ 37:1353-1367. doi:10.1080/00036840500118762

Shan J, Morris AG, Sun F (2001) Financial development and economic growth: an egg-and-chicken problem? Rev Int Econ 9:443-454. doi:10.1111/1467-9396.00291

Shaw E (1973) Financial deepening in economic development. Oxford University Press, New York 